\title{
Phosphinoureas: Cooperative Ligands in Rhodium-Catalyzed Hydroformylation? On the Possibility of a Ligand-Assisted Reductive Elimination of the Aldehyde
}

\author{
Jurjen Meeuwissen ${ }^{\dagger}$ Albertus J. Sandee, ${ }^{\dagger}, \star$ Bas de Bruin,${ }^{\dagger}$ Maxime A. Siegler,${ }^{\S}$ \\ Anthony L. Spek, ${ }^{\S}$ and Joost N. H. Reek*, ${ }^{*}$ \\ ${ }^{\dagger}$ Van't Hoff Institute for Molecular Sciences, University of Amsterdam, Nieuwe Achtergracht 166, $1018 \mathrm{WV}$ \\ Amsterdam, The Netherlands, "BASF Nederland B.V. Catalysts, Strijkviertel 67, 3454 PK De Meern, \\ The Netherlands, and ${ }^{\S}$ Crystal and Structural Chemistry, Bijvoet Centre for Biomolecular Research, \\ Faculty of Science, Utrecht University, Padualaan 8, 3584 CH Utrecht, The Netherlands
}

Received November 27, 2009

\begin{abstract}
We report the synthesis of a novel type of phosphinourea ligand, its coordination chemistry with rhodium, its use in the asymmetric hydroformylation of styrene, and investigations on the hydroformylation reaction mechanism. Complex studies on the 2:1 complex of phosphinourea to [Rh(acac)$\left.(\mathrm{CO})_{2}\right]$ showed that a neutral trans-coordinating complex $\left[\mathrm{Rh}(H \mathrm{~L}-\kappa P)\left(\mathrm{L}-\kappa^{2} O, P\right)(\mathrm{CO})\right]$ was formed. An anionic $O, P$-chelating ligand has displaced the anionic acac ${ }^{-}$ligand via an acid-base reaction involving the deprotonation of an acidic urea proton, giving Hacac. A second phosphinourea is coordinated as a neutral monodentate ligand and is linked to the chelating anionic ligand via an intramolecular hydrogen bond. The behavior of these supramolecular complexes in the hydroformylation reaction and the possible cooperative role of the ligands in the catalytic cycle were studied both experimentally and by computational methods. High-pressure NMR spectroscopy revealed that the catalytically active rhodium hydride species further consists of two neutral phosphinourea ligands and is in equilibrium with the neutral species $\left[\mathrm{Rh}(H \mathrm{~L}-\kappa P)\left(\mathrm{L}-\kappa^{2} O, P\right)(\mathrm{CO})\right]$. This equilibrium is likely an integrated part of a productive hydroformylation cycle involving a ligand-assisted reductive elimination of the aldehyde. DFT calculations revealed that the ligand-assisted mechanism could well be the preferred lower energetic pathway; however, the orientation of the anionic oxygen donor atom in $\left[\mathrm{Rh}(H \mathrm{~L}-\kappa P)\left(\mathrm{L}-\kappa^{2} O, P\right)(\mathrm{CO})\right]$ prevented us from finding a direct (nonsolvent assisted) transition state to connect the intermediates. We therefore cannot exclude a mechanism where $\left[\mathrm{Rh}(H \mathrm{~L}-\kappa P)\left(\mathrm{L}-\kappa^{2} O, P\right)-\right.$ $(\mathrm{CO})]$ is a dormant species outside the productive hydroformylation cycle, although the intermediate associated with this mechanism is higher in energy. Finally, the synthesis of heteroligated complexes was investigated, consisting of two electronically different phosphinoureas, which sets the stage for combinatorial supramolecular ligand approaches in catalysis. Simply mixing two electronically different phosphinoureas with metal precursor $\left[\mathrm{Rh}(\mathrm{acac})(\mathrm{CO})_{2}\right]$ resulted in the formation of a heterobidentate ligand. A set of six new phosphinoureas was used to prepare such rhodium complexes in a combinatorial fashion for the asymmetric hydroformylation of styrene, resulting in high conversions and selectivities for the branched product and moderate enantioselectivities.
\end{abstract}

\section{Introduction}

Traditionally, "catalysis by ligand design" means that variation of the steric and electronic properties of ligands is used to influence the catalytic performance of a catalyst as a whole. More recently, new developments invoke a more active role of the ligands, in which they are considered as

\footnotetext{
*To whom correspondence should be addressed. E-mail: j.n.h.reek@ uva.nl. Fax: +31 (0)20 525 6422. Tel: +31 (0)20 5256437.

(1) (a) Breuil, P.-A. R.; Patureau, F. W.; Reek, J. N. H. Angew. Chem., Int. Ed. 2009, 48, 2162-2165. (b) Šmejkal, T.; Breit, B. Angew. Chem., Int. Ed. 2008, 47,311-315. (c) Śmejkal, T.; Breit, B. Angew. Chem., Int. Ed. 2008, 47, 3946-3949. (d) Grünanger, C. U.; Breit, B. Angew. Chem., Int. Ed. 2008, 47, 7346-7349. (e) Börner, A. Chirality 2001, 13, 625-628. (f) Börner, A. Eur. J. Inorg. Chem. 2001, 327-337. (g) Sawamura, M.; Ito, Y.
} Chem. Rev. 1992, 92, 857-871. an integrated part of the catalyst, strongly partaking in the reaction mechanism. Among such integrated catalysts are ligands capable of substrate orientation, ${ }^{1}$ hemilabile (hybrid) ligands, ${ }^{2}$ cooperative ligands,,${ }^{3,4}$ or a combination these functionalities. Ligands with functionality for substrate orientation preorganize the substrate in a favorable way to

(2) (a) Braunstein, P. J. Organomet. Chem. 2004, 689, 3953-3967. (b) Braunstein, P.; Naud, F. Angew. Chem., Int. Ed. 2001, 40, 680-699.

(3) Grützmacher, H. Angew. Chem., Int. Ed. 2008, 47, 1814-1818

(4) (a) Patureau, F. W.; Kuil, M.; Sandee, A. J.; Reek, J. N. H. Angew. Chem., Int. Ed. 2008, 47, 3180-3183. (b) Gunanathan, C.; Ben-David, Y.; Milstein, D. Science 2007, 317, 790-792. (c) Zweifel, T.; Naubron, J.-V.; Grützmacher, H. Angew. Chem., Int. Ed. 2009, 48, 559-563. (d) Maire, P.; Böttner, T.; Breher, F.; Le Floch, P.; Grützmacher, H. Angew. Chem., Int. Ed. 2005, 44, 6318-6323. (e) Noyori, R.; Yamakawa, M.; Hashiguchi, S. J. Org. Chem. 2001, 66, 7931-7944. 

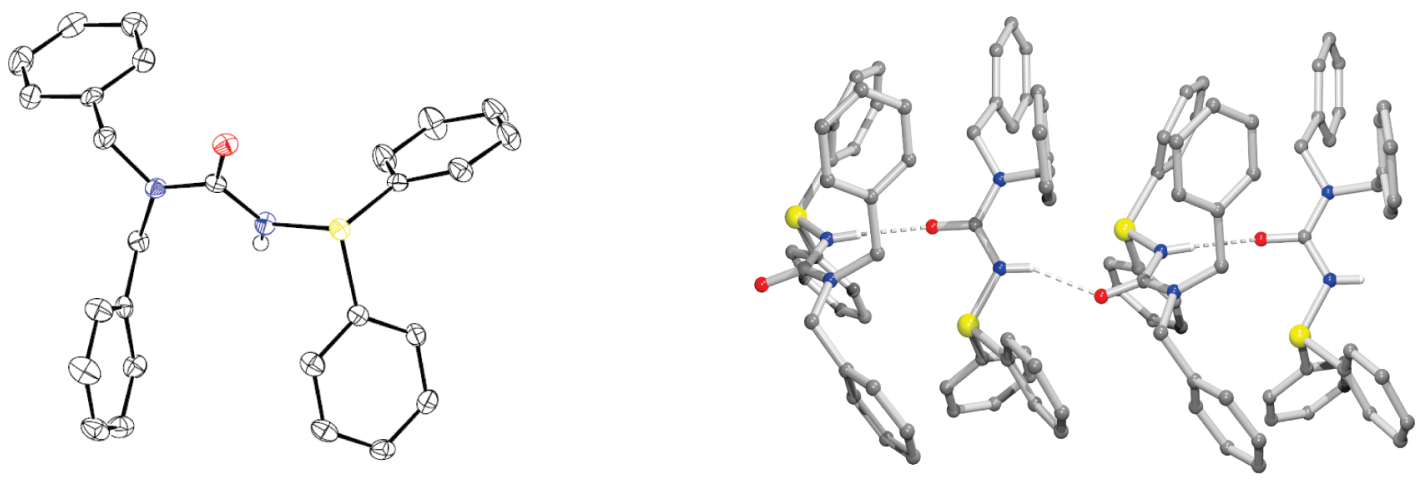

Figure 1. (Left) Displacement ellipsoid plot (50\% probability level) of one of the two crystallographically independent molecules of HL1 (CH hydrogen atoms omitted for clarity). The molecules link into infinite chains through NH $\cdots$ O hydrogen bonds. (Right) POVRay picture showing the $1 \mathrm{D}$ chain built of molecules of $\boldsymbol{H L} \mathbf{1}$ via $\mathrm{N}-\mathrm{H} \cdots$ O hydrogen bond interactions $(2.109$ and $2.177 \AA$ ). P: yellow, O: red, N: blue, C: black, H: white.

enhance selectivity and activity. Breit and Reek exploited hydrogen bonding as a tool for substrate orientation. This strategy was demonstrated to be effective for the highly selective hydroformylation of unsaturated carboxylic acids with guanidinium-functionalized phosphines ${ }^{1 \mathrm{~b}, \mathrm{c}}$ and for the hydrogenation of 2-hydroxymethylacrylate using a supramolecular heterobidentate ligand ${ }^{5}$ of LEUPhos $^{1 \mathrm{a}}$ and a urea-functionalized phosphine. In these examples hydrogen bonding between the substrate and the ligand plays a crucial role to obtain high selectivity. Hemilabile ligands generally consist of a strongly coordinating donor atom and an additional weakly coordinating donor atom that can temporarily coordinate to the transition metal to stabilize reactive intermediates. Cooperative ligands were recently defined by Grützmacher ${ }^{3}$ as ligands that participate directly in a bond activation reaction and undergo reversible chemical transformations. Milstein combined hemilabile and cooperative functionalities in a $\mathrm{Ru}^{\mathrm{II}}$ complex based on a 2-(di-tert-butylphosphinomethyl)-6-(diethylaminomethyl)pyridine "pincer" ligand for the unprecedented dehydrogenative coupling of alcohols and amines to yield amides. ${ }^{4 c}$ The reversible ligandassisted heterolytic splitting of $\mathrm{H}_{2}$ was observed to be a key step in the mechanism. These examples clearly demonstrate that the role of the ligand in transition metal catalysis may be far less static than originally anticipated. In this paper we report on a new type of phosphinourea ligand that forms heterobidentate rhodium complexes via self-assembly. The experimental and computational studies point at a ligandassisted (cooperative) mechanism in hydroformylation, implying an active role of this particular ligand in this reaction. Interestingly, the approach can be extended to supramolecular heterobidentate ligands, which sets the stage for combinatorial approaches. This is demonstrated by the preparation of 14 complexes using combinations of phosphinourea ligands and their application in the asymmetric hydroformylation reaction.

\section{Results and Discussion}

The general procedure for the preparation of phosphinourea ligands described in this paper consists of two steps: (1) the conversion of a secondary amine into a $N, N$-disubstituted urea, followed by (2) a condensation reaction of the $N, N$ -

(5) (a) Wilkinson, M. J.; van Leeuwen, P. W. N. M.; Reek, J. N. H. Org. Biomol. Chem. 2005, 3, 2371-2383. (b) Breit, B. Angew. Chem., Int. Ed. 2005, 44, 6816-6825. (c) Sandee, A. J.; Reek, J. N. H. Dalton Trans. 2006, 3385-3391.
Scheme 1. Synthesis of Phosphinourea Ligand $H \mathrm{~L} 1$

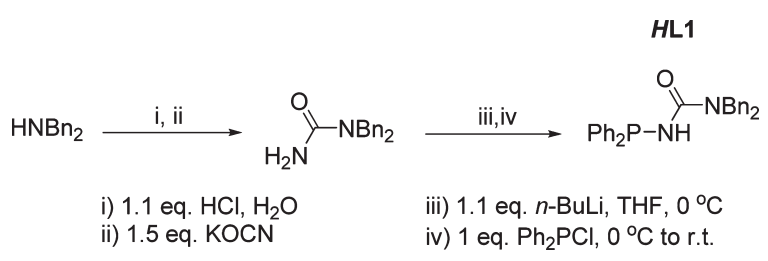

disubstituted urea with a $\mathrm{PCl}$ compound. ${ }^{6,7}$ These ligands all contain a phosphorus donor atom directly connected to a urea motif. For example, phosphorus amide $\boldsymbol{H} \mathbf{L} \mathbf{1}$ was prepared by converting $N, N$-dibenzyl urea into a lithium salt, which was subsequently reacted with chlorodiphenylphosphine (Scheme 1). The X-ray structure of $\boldsymbol{H L 1}$ shows that in the solid state the molecules are linked through hydrogen bonding via the urea motif (Figure 1).

Addition of two equivalents of $\boldsymbol{H L 1}$ to a solution of $\left[\mathrm{Rh}(\mathrm{acac})(\mathrm{CO})_{2}\right]$ in $\mathrm{CDCl}_{3}$ resulted in the formation of a yellow solution of complex $\left[\operatorname{Rh}(\boldsymbol{H L 1}-\kappa P)\left(\mathbf{L} \mathbf{1}-\kappa^{2} O, P\right)(\mathrm{CO})\right]$ (Scheme 2, I). ${ }^{4 \mathrm{a}, 8}$ Two doublets of doublets resonating at $\delta$ $62.9 \mathrm{ppm}\left({ }^{1} J_{\mathrm{P}-\mathrm{Rh}}=135 \mathrm{~Hz}\right)$ and at $\delta 82.0 \mathrm{ppm}\left({ }^{1} J_{\mathrm{P}-\mathrm{Rh}}=129\right.$ $\mathrm{Hz}$ ) are visible in the ${ }^{31} \mathrm{P}\left\{{ }^{1} \mathrm{H}\right\}$ NMR spectrum. The large $\mathrm{P}-\mathrm{P}$ coupling constant $\left({ }^{2} J_{\mathrm{P}-\mathrm{P}}=326 \mathrm{~Hz}\right)$ indicates that two inequivalent phosphorus ligands are in mutual trans-positions (Scheme 2, II). The ${ }^{1} \mathrm{H}$ NMR spectrum shows free acetylacetone (Hacac) displaced from the metal complex and that one urea proton has disappeared. This implies that the acidic urea proton has been transferred to $\mathrm{acac}^{-}$, yielding Hacac and an anionic ligand $\mathbf{L 1}^{-}$, which presumably coordinates in a bidentate fashion $\left(\kappa^{2} P, O\right)$, forming a five-membered ring. ${ }^{9}$

(6) A similar phosphinourea ligand was reported before; see: Marchenko, A. P.; Koydan, G. K.; Smaliy, R. V.; Chaykovskaya, A. A.; Pinchuk, A. M.; Tolmachev, A. A.; Shishkin, O. V. Eur. J. Inorg. Chem. 2008, 3348-3352.

(7) For reports on related compounds see: (a) Kühl, O.; Lönnecke, P. Inorg. Chem. 2002, 41, 4315-4317. (b) Kühl, O. Dalton Trans. 2003, 949-952. (c) Kühl, O. Coord. Chem. Rev. 2006, 250, 2867-2915. (d) Bhattacharyya, P.; Slawin, A. M. Z.; Smith, M. B.; Williams, D. J.; Woollins, J. D. J. Chem. Soc., Dalton Trans. 1996, 3647-3651. (e) Slawin, A. M. Z.; Wainwright, M.; Woollins, J. D. J. Chem. Soc., Dalton Trans. 2001, 2724-2730.

(8) For similar metal complexes see: (a) Fuentes, J. A.; Clarke, M. L.; Slawin., A. M. Z. New J. Chem. 2008, 32, 689-693. (b) Trzeciak, A. M.; Štěpnička, P.; Mieczyńska, A. E.; Ziółkowski, J. J. J. Organomet. Chem. 2005, 690, 3260-3267. (c) Trzeciak, A. M.; Ziółkowski, J. J.; Tadeusz, L.; Choukroun, R. J. Organomet. Chem. 1999, 575, 87-97.

(9) A related anionic phosphinoamide ligand has been found to coordinate to rhodium via a $O, P$ chelate; see: Braunstein, P.; Heaton, B. T.; Jacob, C.; Manzi, L.; Morise, X. Dalton Trans. 2003, 1396-1401. 
Scheme 2. (I) Reactivity of $H \mathrm{~L} 1$ with $\left[\mathrm{Rh}(\operatorname{acac})(\mathrm{CO})_{2}\right]$; (II) ${ }^{31} \mathbf{P}\left\{{ }^{1} \mathrm{H}\right\}$ NMR spectrum of the resulting $\operatorname{complex}\left[\operatorname{Rh}(H \mathrm{~L} 1-\kappa P)\left(\mathrm{L} 1-\kappa^{2} O, P\right)-\right.$ (CO)] (20 $\mathrm{mM}$ in $\left.\mathrm{CDCl}_{3}\right)$

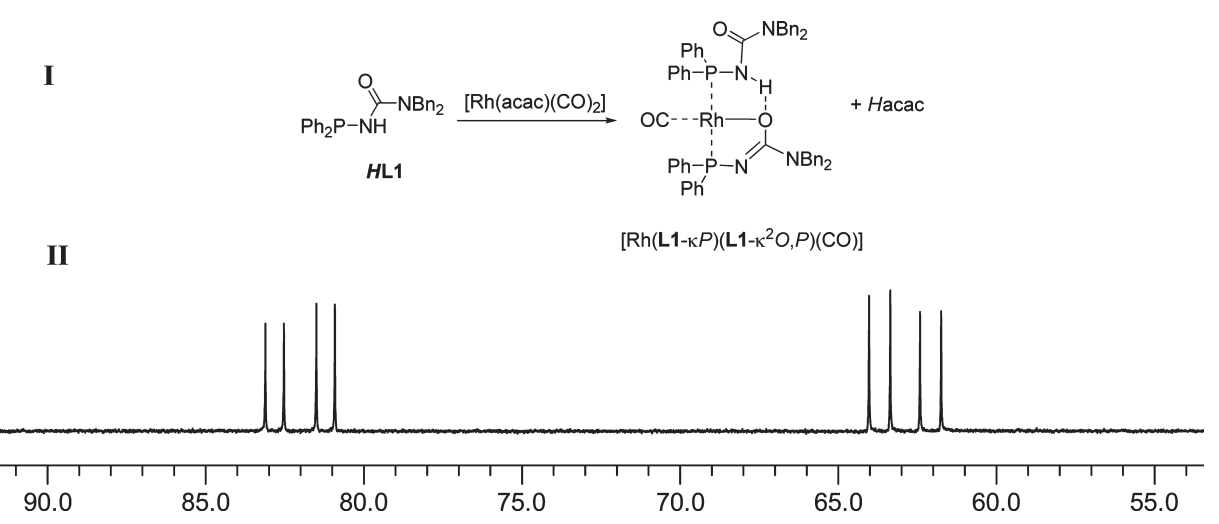

Additional proof for the urea proton abstraction from one of the ligands was obtained by proton-coupled ${ }^{31} \mathrm{P}$ NMR spectroscopy, showing that the signal resonating at $\delta 62.9 \mathrm{ppm}$ has retained the $\mathrm{P}-\mathrm{H}$ coupling $\left({ }^{2} J_{\mathrm{P}-\mathrm{H}}=14.6 \mathrm{~Hz}\right.$, $\mathrm{P}$ with the urea proton) and thus corresponds to the neutral ligand. The signal resonating at $\delta 82.0 \mathrm{ppm}$ lacks this coupling and thus corresponds to the (deprotonated) anionic ligand. ${ }^{10}$ The ${ }^{31} \mathrm{P}\left\{{ }^{1} \mathrm{H}\right\}-{ }^{1} \mathrm{H}$ 2D-NMR spectrum shows that the single urea proton in the ${ }^{1} \mathrm{H}$ NMR correlates to the signal resonating at $\delta$ $62.9 \mathrm{ppm}$ in the ${ }^{31} \mathrm{P}\left\{{ }^{1} \mathrm{H}\right\} \mathrm{NMR}$ spectrum, providing further evidence that this peak corresponds to the neutral ligand. ${ }^{10}$

The urea proton signal in the ${ }^{1} \mathrm{H}$ NMR spectrum of the neutral ligand in the complex has shifted downfield by $\sim 1.4 \mathrm{ppm}$ compared to the free ligand, indicating that this proton is involved in hydrogen bonding, presumably via the coordinating oxygen atom of the anionic ligand (Scheme 2). ${ }^{11}$ The proposed geometry of $\left[\mathrm{Rh}(\boldsymbol{H} \mathbf{L} \mathbf{1}-\kappa P)\left(\mathbf{L} \mathbf{1}-\kappa^{2} O, P\right)(\mathrm{CO})\right]$ in Scheme 2 , I, is supported by the DFT-optimized structure (benzyl groups simplified to methyl groups), showing the two P atoms of the chelating anionic ligand and the neutral ligand in a transgeometry (Figure 2). ${ }^{12,14}$ The anionic ( $\pi$-donating) oxygen donor and the $\pi$-accepting $\mathrm{CO}$ ligand coordinate preferably in mutual trans-positions for electronic reasons. ${ }^{13}$ The DFT-optimized structure further reveals a $\mathrm{NH} \cdots \mathrm{O}$ distance of $1.973 \AA$, indicative of hydrogen bonding. ${ }^{14}$ The complex was further characterized by solution IR spectroscopy, showing the coordinated CO ligand $\left(v(\mathrm{CO})=1970 \mathrm{~cm}^{-1}\right)$, and mass spectrometry ( $m / z$ calcd for $\mathrm{C}_{54} \mathrm{H}_{49} \mathrm{~N}_{4} \mathrm{O}_{2} \mathrm{P}_{2} \mathrm{Rh} 950.2386$, found 950.2380 (CO ligand dissociated)).

We subsequently investigated the activity of $[\mathrm{Rh}(\boldsymbol{H} \mathbf{L} \mathbf{1}-\kappa P)-$ $\left.\left(\mathbf{L} \mathbf{1}-\kappa^{2} O, P\right)(\mathrm{CO})\right]$ in the hydroformylation of styrene, while

(10) See Supporting Information.

(11) For other examples of supramolecular urea-functionalized ligands see: (a) Meeuwissen, J.; Kuil, M.; van der Burg, A. M.; Sandee, A. J.; Reek, J. N. H. Chem.-Eur. J. 2009, 15, 10272-10279. (b) Sandee, A. J.; van der Burg, A. M.; Reek, J. N. H. Chem. Commun. 2007, 864-866. (c) Knight, L. K.; Freixa, Z.; van Leeuwen, P. W. N. M.; Reek, J. N. H. Organometallics 2006, 25, 954-960. (d) Duckmanton, P. A.; Blake, A. J.; Love, J. B. Inorg. Chem. 2005, 44, 7708-7710. (e) Yoo, H.; Mirkin, C. A.; DiPasquale, A. G.; Rheingold, A. L.; Stern, C. L. Inorg. Chem. 2008, 47, 9727-9729.

(12) We have attempted several times to crystallize $[\operatorname{Rh}(\boldsymbol{H L} \mathbf{1}-\kappa P)-$ $\left.\left(\mathbf{L} 1-\kappa^{2} O, P\right)(\mathrm{CO})\right]$; however we were not able to obtain crystals suitable for X-ray analysis.

(13) (a) Tejel, C.; Ciriano, M. A.; del Río, M. P.; Hetterscheid, D. G. H.; Tsichlis i Spithas, N.; Smits, J. M. M.; de Bruin, B. Chem Eur. J. 2008, 14, 10932-10936. (b) Tejel, C.; del Río, M. P.; Ciriano, M. A.; Reijerse, E. J.; Hartl, F.; Záliš, A.; Hetterscheid, D. G. H.; Tsichlis i Spithas; de Bruin, B. Chem.-Eur. J. 2009, 15, 11878-11889.

(14) The corresponding anionic N-bound chelate is $16 \mathrm{kcal}^{\mathrm{mol}}{ }^{-1}$ higher in energy than the anionic O-bound chelate.

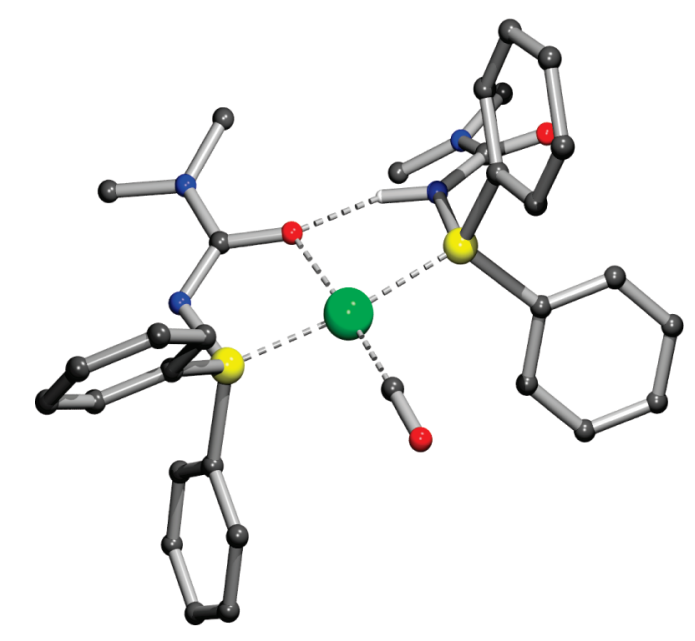

Figure 2. DFT (BP86, SV(P))-optimized structure of $[\mathrm{Rh}(H \mathrm{~L}$ $\left.\kappa P)\left(\mathrm{L}-\kappa^{2} O, P\right)(\mathrm{CO})\right], H \mathrm{~L}=1,1$-dimethyl-3-(diphenylphosphino)urea $\left(\mathrm{Rh}-\mathrm{CO} 1.818 \AA, \mathrm{Rh}-\mathrm{P}(\kappa P) 2.349 \AA, \mathrm{Rh}-\mathrm{P}\left(\kappa^{2} O, P\right)\right.$

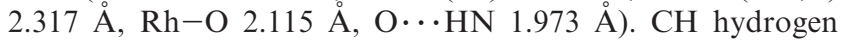
atoms are omitted for clarity. Rh: green, $\mathrm{P}$ : yellow, O: red, N: blue, C: black, H: white.

Table 1. Hydroformylation of Styrene Using $[\operatorname{Rh}(H \mathrm{~L} 1-\kappa P)-$

\begin{tabular}{cccccc}
\multicolumn{6}{c}{$\left.\left(\mathbf{L 1}-\kappa^{\mathbf{2}} \boldsymbol{O}, \boldsymbol{P}\right)(\mathbf{C O})\right]^{\boldsymbol{a}}$} \\
entry & $\begin{array}{c}\mathrm{Rh} \\
{[\mathrm{mM}]}\end{array}$ & $\begin{array}{c}p \mathrm{CO} \\
(\text { bar })\end{array}$ & $\begin{array}{c}p \mathrm{H}_{2} \\
(\text { bar })\end{array}$ & $\begin{array}{c}\text { conversion } \\
(\%)\end{array}$ & $\begin{array}{c}\text { branched } \\
(\%)\end{array}$ \\
\hline 1 & 1 & 10 & 10 & 6.2 & 95.8 \\
2 & 5 & 10 & 10 & 26.5 & 95.3 \\
3 & 10 & 10 & 10 & 32.3 & 95.4 \\
4 & 15 & 10 & 10 & 33.2 & 95.3 \\
5 & 5 & 10 & 30 & 62.0 & 95.4 \\
6 & 5 & 30 & 10 & 18.7 & 96.2 \\
7 & 5 & 20 & 20 & 22.2 & 96.0
\end{tabular}

${ }^{a}$ Reaction conditions: $\mathrm{Rh}=\left[\mathrm{Rh}(\mathrm{acac})(\mathrm{CO})_{2}\right],[$ HL1 $]=2.1 \times[\mathrm{Rh}]$, $[\mathrm{S}]=1 \mathrm{M}, \mathrm{S}=$ styrene, reaction time $=6 \mathrm{~h}$, temperature $=40^{\circ} \mathrm{C}$, solvent $=\mathrm{CH}_{2} \mathrm{Cl}_{2}$.

varying several reaction parameters, such as the rhodium concentration and the partial pressures of $\mathrm{CO}$ and $\mathrm{H}_{2}$ (Table 1). The complex is indeed an active catalyst and showed in all cases good selectivity for the branched product (95.3-96.2\%). Because it is generally believed that a hydride species is the actual catalytically active species in hydroformylation, we initially considered $\left[\operatorname{Rh}(\boldsymbol{H} \mathbf{L} \mathbf{1}-\kappa P)\left(\mathbf{L} \mathbf{1}-\kappa^{2} O, P\right)(\mathrm{CO})\right]$ merely as a precursor complex for a hydride-containing 


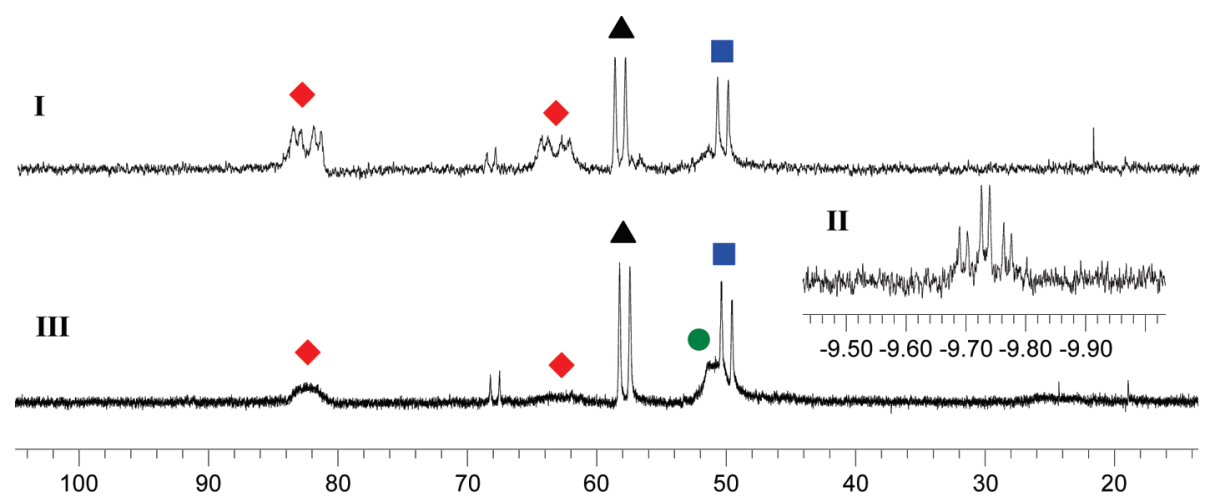

Figure 3. (I) High-pressure ${ }^{31} \mathrm{P}\left\{{ }^{1} \mathrm{H}\right\}$ NMR spectrum of $\left[\mathrm{Rh}(\boldsymbol{H L 1}-\kappa P)\left(\mathbf{L} 1-\kappa^{2} O, P\right)(\mathrm{CO})\right]$ at 10 bar of CO/H $\mathrm{H}_{2}$ (II) ${ }^{1} \mathrm{H} \mathrm{NMR}$ spectrum at 20 bar of $\mathrm{CO} / \mathrm{H}_{2}$. (III) ${ }^{31} \mathrm{P}\left\{{ }^{1} \mathrm{H}\right\}$ NMR spectrum at 20 bar of $\mathrm{CO} / \mathrm{H}_{2}$. Conditions: $[\mathrm{Rh}]=40 \mathrm{mM}$, temp $=25^{\circ} \mathrm{C}$, solvent $=\mathrm{CD}_{2} \mathrm{Cl}_{2}$. The precursor complex $\left[\mathrm{Rh}(\boldsymbol{H L} \mathbf{1}-\kappa P)\left(\mathbf{L} \mathbf{1}-\kappa^{2} O, P\right)(\mathrm{CO})\right]$ is represented by the red diamonds.

species that is formed under hydroformylation conditions. ${ }^{15}$ An increase of the rhodium concentration from 1 to $15 \mathrm{mM}$ led to an increase of the conversion from 6.2 to $33.2 \%$ (compare entries 1-4). However, when the rhodium concentration exceeds $5-10 \mathrm{mM}$, the conversion does not increase further presumably due to formation of inactive carbonylbridged dimeric rhodium species. ${ }^{16}$ An increase of the partial $\mathrm{CO}$ pressure from 10 to 30 bar gave a decrease of the conversion from 26.5 to $18.7 \%$ (compare entries 2 and 6). Such a trend is normally observed in this reaction; ${ }^{15}$ however, an increase in the partial $\mathrm{H}_{2}$ pressure from 10 to 30 bar led to a remarkably strong increase of the conversion from 26.5 to $62.0 \%$ (compare entries 2 and 5). This result indicates that an increase of the partial $\mathrm{H}_{2}$ pressure promotes the formation of the catalytically active hydride species from precursor complex $\left[\operatorname{Rh}(\boldsymbol{H L 1}-\kappa P)\left(\mathbf{L 1}-\kappa^{2} O, P\right)(\mathrm{CO})\right]$, which is likely still present in the reaction mixture under these conditions.

Accordingly, we studied the anticipated precursor complex $\left[\operatorname{Rh}(\boldsymbol{H} \mathbf{L} \mathbf{1}-\kappa P)\left(\mathbf{L} \mathbf{1}-\kappa^{2} O, P\right)(\mathbf{C O})\right]$ under hydroformylation conditions via high-pressure NMR spectroscopy to observe the formation of the hydride species. The ${ }^{31} \mathrm{P}\left\{{ }^{1} \mathrm{H}\right\}$ NMR spectrum of the precursor complex in $\mathrm{CD}_{2} \mathrm{Cl}_{2}$ under a pressure of syngas (10 bar) shows that the precursor complex giving rise to the signals resonating at $\delta 63.0$ and $81.9 \mathrm{ppm}$ remains present in solution (Figure 3 , I, red diamonds). The other major signals visible in the spectrum are a doublet resonating at $\delta 49.8 \mathrm{ppm}\left(J_{\mathrm{Rh}-\mathrm{P}}=163 \mathrm{~Hz}\right.$, blue squares $)$, a broad signal resonating at $\delta 51 \mathrm{ppm}$ (black triangle), and a doublet resonating at $\delta 58.1 \mathrm{ppm}\left(J_{\mathrm{Rh}-\mathrm{P}}=166 \mathrm{~Hz}\right.$, green circle) (Figure 3, I). One of these signals most likely belongs to the carbonyl-bridged dimeric rhodium species, as the NMR experiment is done at relatively high concentrations. In line with this, the color of the solution in the NMR tube turned to orange under syngas pressure, which is typical for this dirhodium species. ${ }^{16}$ The ${ }^{1} \mathrm{H}$ NMR spectrum shows a single hydride signal (triplets of doublets) resonating at $\delta-9.74 \mathrm{ppm}\left({ }^{1} J_{\mathrm{H}-\mathrm{Rh}}=6.7 \mathrm{~Hz},{ }^{2} J_{\mathrm{H}-\mathrm{P}}=18 \mathrm{~Hz}\right)$, which indicates that the hydride species is present in the solution carrying two equivalent ligands (Figure 3, II). ${ }^{17}$ The rela-

(15) Van Leeuwen, P. W. N. M.; Claver, C., Eds. Rhodium Catalyzed Hydroformylation; Kluwer Academic Publishers: Dordrecht, The Netherlands, 2000

(16) Chan, A. S. C.; Shieh, H.-S.; Hill, J. R. J. Chem. Soc., Chem. Commun. 1983, 688-689.

(17) Attempts to obtain the proton-coupled ${ }^{31} \mathrm{P}$ NMR spectrum in order to correlate couplings with the ${ }^{1} \mathrm{H}$ NMR spectrum failed, because of too large broadening of the peaks. tively small $\mathrm{H}-\mathrm{P}$ coupling constant reveals that the two ligands are predominantly coordinated in a bis-equatorial geometry. ${ }^{18}$ The typical signals in the NMR spectra indicate that the identical coordinated ligands are both neutral. To convert precursor complex $\left[\operatorname{Rh}(\boldsymbol{H L} \mathbf{1}-\kappa P)\left(\mathbf{L} \mathbf{1}-\kappa^{2} O, P\right)(\mathrm{CO})\right]$ into the hydride species, it reacts with a dihydrogen molecule to form a rhodium hydride and to transform the anionic chelating ligand into a neutral ligand. Increasing the pressure in the NMR tube to 20 bar of syngas decreased the amount of precursor complex in the solution in favor of the other species, which indicates that the composition of the reaction mixture is dependent on the pressure applied (Figure 3, III). These results are in accordance with studies by Trzeciak and Stěpnička on a related bis-ligated rhodium complex containing a neutral and an anionic $O, P$-chelating ligand. ${ }^{8 \mathrm{~b}}$ They found that with this type of complexes the hydride species is generated under hydroformylation conditions and also carries two neutral monodentate ligands. ${ }^{8 \mathrm{~b}}$ Depressurization of the solution in the NMR tube and changing to an atmosphere of argon regenerated the precursor complex $\left[\mathrm{Rh}(\boldsymbol{H L} \mathbf{1}-\kappa P)\left(\mathbf{L} \mathbf{1}-\kappa^{2} O, P\right)(\mathrm{CO})\right]$ almost completely. These results imply that the precursor complex and the hydride species are in equilibrium, and the distribution of the species involved in this equilibrium is influenced by the pressure applied, in particular the partial pressure of $\mathrm{H}_{2}$. Indeed, an increased hydroformylation activity of the precursor complex was observed by increasing the partial pressure of $\mathrm{H}_{2}$, which is now well explained by the increase in the concentration of the active species (Table 1).

The NMR studies indicate a relatively fast establishment of the equilibrium between the hydride species and the precursor complex $\left[\mathrm{Rh}(\boldsymbol{H} \mathbf{L} \mathbf{1}-\kappa P)\left(\mathbf{L} \mathbf{1}-\kappa^{2} O, P\right)(\mathrm{CO})\right]$, which suggests that this complex is active in the hydroformylation reaction without a significant incubation time. To verify the absence of an incubation time, the hydroformylation of styrene using this complex was monitored via IR spectroscopy in combination with GC chromatography. Indeed, the kinetic profile shows immediate activity after pressurizing the reaction mixture with syngas, and there is no observable incubation time (Figure 4). ${ }^{10}$ Furthermore, the positive order in alkene indicates that this system follows type I kinetics and that the observed positive order in $\mathrm{H}_{2}$ in Table 1 is not related to type II kinetics, but merely to the equilibrium between the precursor complex and the hydride species. ${ }^{15}$

(18) Buisman, G. J. H.; van der Veen, L. A.; Kamer, P. C. J.; van Leeuwen, P. W. N. M. Organometallics 1997, 16, 5681-5687. 


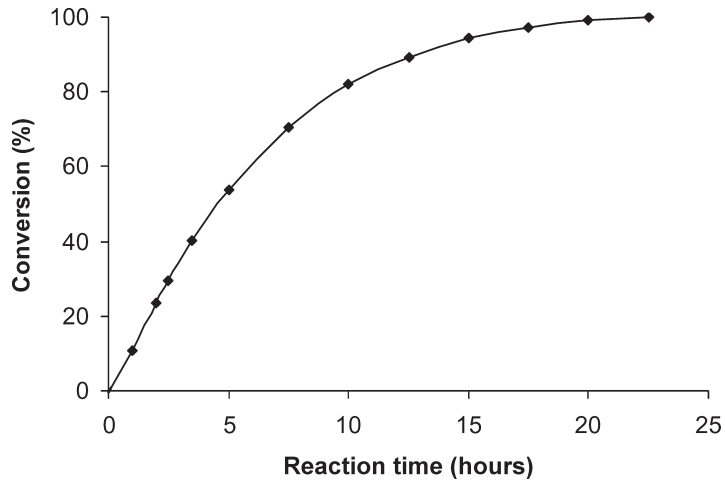

Figure 4. Kinetic profile of the hydroformylation of styrene using $\left[\mathrm{Rh}(\boldsymbol{H L 1} \mathbf{-} \boldsymbol{P})\left(\mathbf{L} \mathbf{1}-\kappa^{2} O, P\right)(\mathrm{CO})\right]$. Reaction conditions: [Rh] $=10$ $\mathrm{mM}, \mathrm{Rh}=\left[\mathrm{Rh}(\mathrm{acac})(\mathrm{CO})_{2}\right],[H \mathrm{~L}]=2.1 \mathrm{mM},[\mathrm{S}]=0.2 \mathrm{M}$, $\mathrm{S}=$ styrene, temp $=40{ }^{\circ} \mathrm{C}$, pressure $=20$ bar of $1: 1 \mathrm{CO} / \mathrm{H}_{2}$, solvent $=\mathrm{CH}_{2} \mathrm{Cl}_{2}$. The reaction was monitored in situ by way of the typical vibrations of the aldehyde product that arise in the IR spectrum with time. The intensity of the vibrations was calibrated by an independent determination of the conversion at the end of the reaction by means of GC ( $\mathrm{GC}$ analysis after $23 \mathrm{~h}$ : conversion $=99 \%$ ).

Although the equilibrium between the precursor complex and the hydride species is established, the position of this equilibrium in the catalytic cycle is still unclear. We considered therefore two conceivable pathways, for which we performed comparative DFT calculations starting from a model precursor complex A: $\left[\mathrm{Rh}(H \mathrm{~L}-\kappa P)\left(\mathrm{L}-\kappa^{2} O, P\right)(\mathrm{CO})\right]$, $\mathrm{L}=$ 1,1-dimethyl-3-(diphenylphosphino)urea (Scheme 4). The initial steps in the catalytic cycle are identical in both pathways. Starting the catalytic cycle from the hydride species $\mathbf{B}$, the acyl species $\mathbf{F}$ is formed via a series of steps involving the association of styrene to form $\mathbf{C}$, migratory insertion of styrene to give $\mathbf{D}$, association of $\mathrm{CO}$ to form $\mathbf{E}$, and another migratory insertion step to form the acyl species $\mathbf{F} .{ }^{19}$ At this point, two different mechanisms are conceivable, which places the equilibrium between $\mathbf{A}$ and $\mathbf{B}$ within the hydroformylation cycle or as a equilibrium between a dormant state $\mathbf{A}$ and intermediate $\mathbf{B}$.

Mechanism 1:. A pre-equilibrium mechanism. An intermolecular reaction involving the oxidative addition of $\mathrm{H}_{2}$ dihydride to $\mathbf{F}$ leads to species $\mathbf{G}^{*}$, which subsequently regenerates $\mathbf{B}$ via reductive elimination of the aldehyde. In this mechanism species $\mathbf{A}$ is in fact a dormant species in a preequilibrium outside the productive catalytic cycle.

Mechanism 2:. A ligand-assisted mechanism analogous to the reaction of phosphinourea ligands with $\left[\mathrm{Rh}(\mathrm{acac})(\mathrm{CO})_{2}\right]$ in Scheme 2, in which an acidic urea proton is transferred from a phosphinourea ligand in $\mathbf{F}$ to the acyl group via the metal center after an intramolecular acid-base reaction. In this pathway, an intramolecular oxidative addition of a phosphinourea ligand forms intermediate $\mathbf{G}^{* *}$, after which reductive elimination of the aldehyde regenerates species $\mathbf{A}$. In this case the equilibrium between $\mathbf{A}$ and $\mathbf{B}$ is part of the catalytic cycle.

So far, we were unable to find a simple (nonsolvent assisted) intramolecular transition state to connect species $\mathbf{F}$ with $\mathbf{G}^{* *}$, because the urea proton from the phosphinourea in $\mathbf{F}$ points in the opposite direction from the urea oxygen (Figure 5). It thus

(19) Species outside the productive cycle are of minor importance to discriminate between the two pathways and are therefore not discussed here. seems that these static gas-phase DFT calculations, which disregard solvent-assisted (de)protonation, are of no further help to truly discriminate between these two possible mechanisms. Nonetheless, it is noteworthy that intermediate $\mathbf{G}^{* *}$, which occurs as a key intermediate in the ligand-assisted mechanism, lies $16.3 \mathrm{kcal} \mathrm{mol}^{-1}$ lower in energy than the intermediate $\mathbf{G}^{*}$, which is the key intermediate in the preequilibrium mechanism. If a low-barrier (solvent assisted) route from $\mathbf{F}$ to $\mathbf{G}$ exists, the ligand-assisted mechanism is the preferred route for the reductive elimination of the aldehyde. In that case, the equilibrium between precursor complex $\mathbf{A}$ and hydride species $\mathbf{B}$ is integrated in the catalytic cycle and a new cooperative ligand-assisted mechanism of hydroformylation is operative.

We have demonstrated that the formation of $[\operatorname{Rh}(\boldsymbol{H L 1}-\kappa P)-$ $\left.\left(\mathbf{L 1}-\kappa^{2} O, P\right)(\mathrm{CO})\right]$ involves a deprotonation of an acidic urea proton of one of the two phosphinourea ligands. Interestingly, this potentially allows the controlled formation of a heterobidentate ligand using two phosphinoureas having different acidity of the urea proton. For this reason, phosphoramidite phosphinourea $\boldsymbol{H} \mathbf{L} \mathbf{2}$ was prepared via a direct condensation reaction of $N, N$-dibenzylurea with a phosphorochloridite of (S)-2,2'-bisnaphthol in the presence of an excess of triethylamine base. This new ligand was fully characterized by ${ }^{1} \mathrm{H},{ }^{13} \mathrm{C}$, and ${ }^{31} \mathrm{P}$ NMR and mass spectrometry. ${ }^{10} \mathrm{By}$ using equimolar equivalents of $\boldsymbol{H L 1}, \boldsymbol{H L 2}$, and $\left[\mathrm{Rh}(\mathrm{acac})(\mathrm{CO})_{2}\right]$ a metal complex was formed that shows in the ${ }^{31} \mathrm{P}\left\{{ }^{1} \mathrm{H}\right\}$ NMR spectrum two doublets of doublets ( $\delta 63.3$ and $170.9 \mathrm{ppm})$, indicating that a heteroligated complex has been formed with a transgeometry of the two phosphorus donor atoms (Scheme 3, I). The ${ }^{31} \mathrm{P}\left\{{ }^{1} \mathrm{H}\right\}$ NMR spectrum of the new complex is very different from $\left[\operatorname{Rh}(\boldsymbol{H L} \mathbf{1}-\kappa P)\left(\mathbf{L} 1-\kappa^{2} O, P\right)(\mathrm{CO})\right](\delta \quad 62.9$ and $82.0 \mathrm{ppm}$ ). In particular the downfield signal at $170.9 \mathrm{ppm}$, which belongs to $\boldsymbol{H} \mathbf{L} \mathbf{2}$, indicates that this ligand forms the anionic chelate instead of $\boldsymbol{H L 1}$ (Scheme 3, II). The ${ }^{1} \mathrm{H}$ NMR spectrum shows that acetylacetone (Hacac) is displaced from the metal complex and that one urea proton is abstracted from HL2. Proton-coupled ${ }^{31} \mathrm{P}$ NMR and ${ }^{31} \mathrm{P}\left\{{ }^{1} \mathrm{H}\right\}-{ }^{1} \mathrm{H} 2 \mathrm{D}-\mathrm{NMR}$ evidenced that the signal resonating at $\delta 63.3 \mathrm{ppm}\left({ }^{1} J_{\mathrm{P}-\mathrm{Rh}}=\right.$ $131 \mathrm{~Hz}$ ), corresponding to $\boldsymbol{H} \mathbf{L} \mathbf{1}$, correlates to the urea proton still visible in the ${ }^{1} \mathrm{H}$ NMR spectrum. This result supports that the signal resonating at $\delta 170.9 \mathrm{ppm}\left({ }^{1} J_{\mathrm{P}-\mathrm{Rh}}=190 \mathrm{~Hz}\right)$, corresponds to $\boldsymbol{H} \mathbf{L} \mathbf{2}$ as an anionic chelating ligand. ${ }^{10}$ So, the ligand carrying the most acidic urea proton donates a proton to the $\mathrm{acac}^{-}$ligand in an acid-base reaction and forms the anionic chelate. This result confirms that by using two electronically different phosphinoureas a heteroligated complex is formed selectively. This provides a new tool in the area of combinatorial catalysis, as a large number of assembled catalysts can be prepared from a subset of well-chosen phosphinourea ligands. ${ }^{20}$

To demonstrate this new tool, we prepared rhodium complexes using six phosphinoureas (HL1-HL6) in a combinatorial

(20) For other examples of catalysts made in combinatorial fashion in rhodium-catalyzed hydroformylation see: (a) Goudriaan, P. E.; Kuil, M.; Jiang, X.-B.; van Leeuwen, P. W. N. M.; Reek, J. N. H. Dalton Trans. 2009, 1801-1805. (b) Kuil, M.; Goudriaan, P. E.; Kleij, A. W.; Tooke, D. M.; Spek, A. L.; van Leeuwen, P. W. N. M.; Reek, J. N. H. Dalton Trans. 2007, 2311-2320. (c) Slagt, V. F.; Röder, M.; Kamer, P. C. J.; van Leeuwen, P. W. N. M.; Reek, J. N. H. J. Am. Chem. Soc. 2004, 126, 4056-4057. (d) Kuil, M.; Goudriaan, P. E.; van Leeuwen, P. W. N. M.; Reek, J. N. H. Chem. Commun. 2006, 4679-4681. (e) Slagt, V. F.; van Leeuwen, P. W. N. M.; Reek, J. N. H. Chem. Commun. 2003, 2474-2475. (f) Slagt, V. F.; van Leeuwen, P. W. N. M.; Reek, J. N. H. Angew. Chem., Int. Ed. 2003, 42, 5619-5623. (g) Breit, B.; Seiche, W. Angew. Chem., Int. Ed. 2005, 44, 1640-1643. (h) Reetz, M. T.; Li, X. Angew. Chem., Int. Ed. 2005, 44, 2962-2964. 
Scheme 3. (I) Reactivity of $H \mathrm{~L} 1$ and $H \mathrm{~L} 2$ with $\left[\operatorname{Rh}(\operatorname{acac})(\mathrm{CO})_{2}\right]$; (II) ${ }^{31} \mathrm{P}\left\{{ }^{1} \mathrm{H}\right\} \mathrm{NMR}$ Spectrum of the $\operatorname{Resulting} \mathrm{Complex}[\mathrm{Rh}(H \mathrm{~L} 1-$ $\left.\kappa P)\left(\mathrm{L} 2-\kappa^{2} O, P\right)(\mathrm{CO})\right]\left(20 \mathrm{mM}\right.$ in $\left.\mathrm{CDCl}_{3}\right)$

I

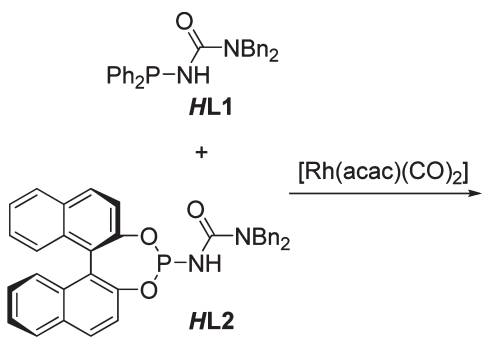

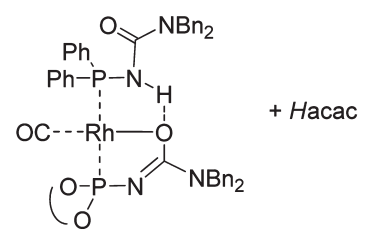

$\left[\operatorname{Rh}(H \mathbf{L} 1-\kappa P)\left(\mathbf{L} 2-\kappa^{2} O, P\right)(C O)\right]$

II

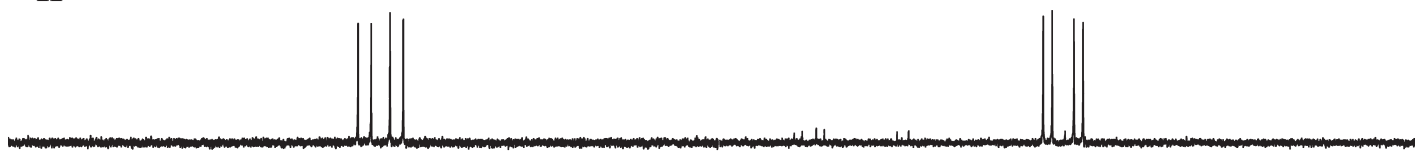

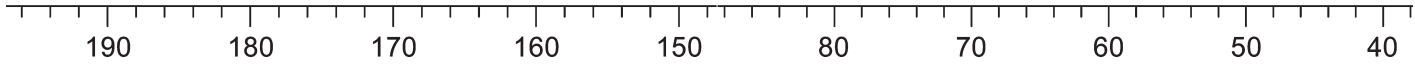

Scheme 4. DFT-Optimized Structures of the Two Mechanistic Pathways in the Hydroformylation of Styrene Using a Phosphinourea Metal Complex via Mechanism 1 (A outside the productive cycle) and Mechanism 2 (A inside the productive cycle) ${ }^{a}$

Mechanism 1

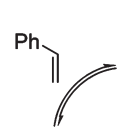<smiles>COC(=O)c1ccccc1</smiles>

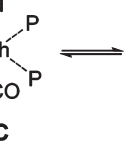<smiles>CC(c1ccccc1)P(P)(P)(P)c1ccccc1</smiles><smiles>CCCCCCCCCCCCC</smiles>

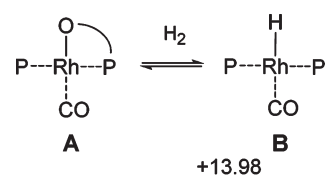
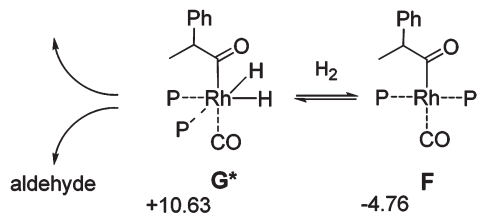

Mechanism 2

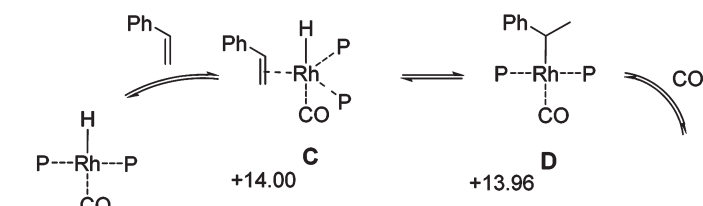

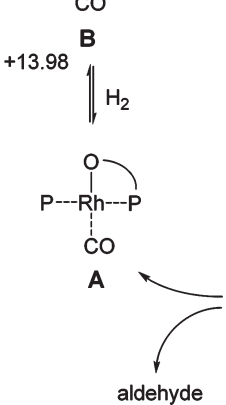<smiles>CC(c1ccccc1)P(=O)(P)C(=O)O</smiles>

${ }^{a}$ Reported energies are relative to species $\mathbf{A}$ in $\mathrm{kcal} \mathrm{mol}^{-1}$. Nonproductive species have been omitted for clarity.

fashion, leading to 14 catalysts in total (6 homocombinations, 8 heterocombinations). These complexes were investigated in the asymmetric hydroformylation of styrene. ${ }^{21}$ Besides $\boldsymbol{H} \mathbf{L} \mathbf{1}$, all other ligands $\boldsymbol{H L 2}-\boldsymbol{H} \mathbf{L 6}$ contain at least one chiral element in their ligand structure (Figure 6). HL4 and $\boldsymbol{H L 6}$ have a urea motif based on $(R, R)$-2,5-diphenylpyrrolidine, while $\boldsymbol{H} \mathbf{L} 2$, $\boldsymbol{H L 3}$, and $\boldsymbol{H L 5}$ contain a BINOL-based backbone. Ligand HL6 contains both chiral elements.

The hydroformylation experiments were carried out at $40{ }^{\circ} \mathrm{C}$ in dichloromethane as a solvent at 20 bar of syngas pressure, and samples were analyzed after $18 \mathrm{~h}$ of reaction. Generally all catalysts gave good conversion (64.1-100\%)

(21) For selected examples for the asymmetric hydroformylation of styrene using traditional bidentate ligands see: (a) Sakai, N.; Mano, S.; Nozaki, K.; Takaya, H. J. Am. Chem. Soc. 1993, 115, 7033-7034. (b) Yan, Y.; Zhang, X. J. Am. Chem. Soc. 2006, 128, 7198-7202. (c) Robert, T.; Abiri, Z.; Wassenaar, J.; Sandee, A. J.; Romanski, S.; Neudörfl, J.-M.; Schmalz, H. G.; Reek, J. N. H. Organometallics 2010, 29, 478-483. and selectivity $(85.7-96.6 \%)$ for the branched product (Table 2). The enantioselectivity displayed by the catalyst depends strongly on the ligands used (ee's between 0 and $46.4 \%$ ). The homocombinations of the BINOL-based phosphoramidites $\boldsymbol{H L 2}, \boldsymbol{H L 3}, \boldsymbol{H L 5}$, and $\boldsymbol{H L 6}$ all lead to poor selectivities, which suggest that this type of backbone is not an effective chiral element in the these complexes for the reaction studied. On the other hand, the homocombination of $\boldsymbol{H L} \mathbf{4}$ was the most selective catalyst, providing an ee of $46.4 \%$. Interestingly, this ligand contains the chirality on the urea motif only, which is remote from the metal center. Experiments in which the metal/ligand ratio was varied showed that the use of three equivalents of $\boldsymbol{H} \mathbf{L} \mathbf{4}$ gave practically the same ee of $45.9 \%$, while using only one equivalent of $\boldsymbol{H L} \mathbf{4}$ caused the ee to decrease to $38.2 \%$ (compare entries 4, 5, and 6). Ligand HL6, which contains a chiral center at the urea motif next to the BINOL backbone, gave poor selectivity (ee 6.8\%). The heteroligated 

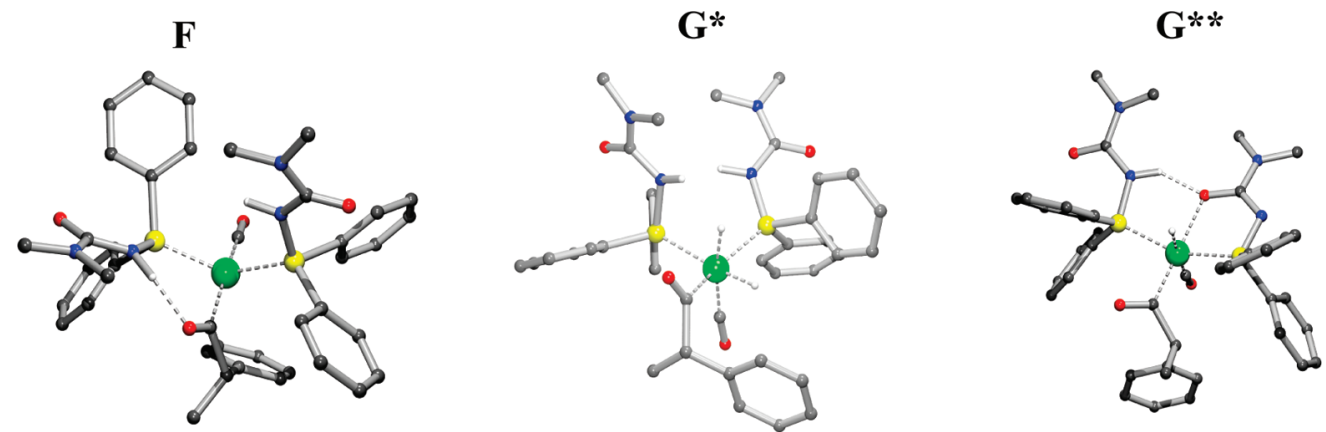

Figure 5. DFT (BP86, SV(P))-optimized structures of intermediates $\mathbf{F}$ (acyl species), $\mathbf{G}^{*}$ (oxidative addition of $\mathrm{H}_{2}$ ), and $\mathbf{G}^{* *}$ (ligandassisted intermediate). $\mathrm{CH}$ hydrogen atoms are omitted for clarity. Rh: green, P: yellow, O: red, N: blue, C: black, H: white.<smiles>O=C(Nc1ccccc1)Nc1ccccc1</smiles>

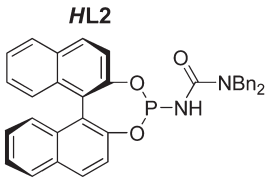<smiles>CC(=O)NP(Oc1ccc2ccccc2c1)Oc1cccc2ccccc12</smiles>

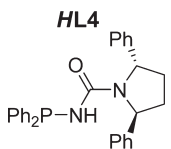

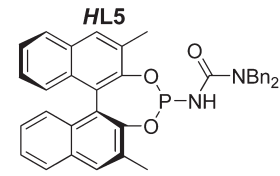<smiles>O=C(NP(Oc1ccc2ccccc2c1)c1cccc2ccccc12)N1C(c2ccccc2)CCC1c1ccccc1</smiles>

Figure 6. Structures of phosphinourea ligands $\boldsymbol{H L 1}-\boldsymbol{H L 6}$.

Table 2. Asymmetric Hydroformylation of Styrene Using $\left[\operatorname{Rh}(H \mathrm{~L}-\kappa P)\left(\mathrm{L}-\kappa^{2} O, P\right)(\mathrm{CO})\right]^{a}$

\begin{tabular}{|c|c|c|c|c|}
\hline entry & ligand & conversion $(\%)$ & branched $(\%)$ & ee $(\%)$ \\
\hline 1 & $H \mathrm{~L} 1$ & 73.1 & 95.6 & \\
\hline 2 & $H \mathrm{~L} 2$ & 100 & 90.9 & $3.2(S)$ \\
\hline 3 & $H \mathrm{L3}$ & 80.6 & 85.7 & 0 \\
\hline 4 & HL4 & 74.7 & 96.5 & $46.4(S)$ \\
\hline $5^{c}$ & HL4 & 99.1 & 96.6 & $38.2(S)$ \\
\hline $6^{d}$ & $H \mathrm{L4}$ & 64.1 & 96.4 & $45.9(S)$ \\
\hline 7 & HL5 & 100 & 93.9 & $3.4(R)$ \\
\hline 8 & HL6 & 100 & 94.5 & $6.8(S)$ \\
\hline 9 & $H \mathrm{~L} 1+H \mathrm{~L} 2$ & 96.7 & 93.8 & $4.5(S)$ \\
\hline 10 & $H \mathrm{~L} 1+H \mathrm{~L} 3$ & 79.7 & 93.2 & 0 \\
\hline 11 & $H \mathrm{~L} 1+H \mathrm{~L} 5$ & 100 & 94.3 & $2.7(S)$ \\
\hline 12 & $H \mathrm{~L} 1+H \mathrm{~L} 6$ & 100 & 93.6 & $5.4(S)$ \\
\hline $13^{b}$ & $H \mathrm{L4}+H \mathrm{~L} 2$ & 91.8 & 94.2 & $24.5(S)$ \\
\hline $14^{b}$ & $H \mathrm{~L} 4+H \mathrm{~L} 3$ & 71.7 & 94.0 & $10.8(S)$ \\
\hline $15^{b}$ & $H \mathrm{L4}+H \mathrm{~L} 5$ & 98.3 & 95.1 & $25.0(S)$ \\
\hline 16 & $H \mathrm{L4}+H \mathrm{~L} 6$ & 100 & 94.2 & $16.9(S)$ \\
\hline
\end{tabular}

complexes were prepared from phosphorus amides $\boldsymbol{H} \mathbf{L} \mathbf{1}$ and HL4 in combination with the more acidic phosphoramidites HL2, HL3, HL5, and HL6. Unfortunately, these complexes did not yield more selective catalysts than the homocombinations in most examples. The most selective heterocombinations were $\boldsymbol{H L} \mathbf{4}+\boldsymbol{H} \mathbf{L} \mathbf{2}$ and $\boldsymbol{H L 4}+\boldsymbol{H L 5}$, giving ee's of 24.5 and $25.0 \%$, respectively.

\section{Conclusions}

In summary, we report the synthesis of new phosphinourea ligands, the preparation of supramolecular homo- and heteroligated rhodium complexes thereof, and their use in the asymmetric hydroformylation of styrene. The hydrofor- mylation reaction may well proceed via a new mechanism involving ligand cooperativity. This mechanism involves the reversible heterolytic splitting of $\mathrm{H}_{2}$ over the metal center and an anionic phosphinourea fragment, and the ligand-assisted reductive elimination of the aldehyde. Computational studies support this ligand-assisted mechanism, but so far we cannot exclude a mechanism in which a dormant state and a rhodium hydride are in equilibrium via a reversible heterolytic splitting of $\mathrm{H}_{2}$ over the metal center, connecting the dormant state with the productive hydroformylation cycle via a pre-equilibrium. The selective formation of heterobidentate ligands of these phosphinoureas is potentially a valuable strategy for the creation of catalyst libraries in a combinatorial fashion for high-throughput screening due to the straightforward ligand synthesis. The first results in this direction demonstrate that the application of a small ligand library already leads to catalysts that showed a high regioselectivity but so far moderate enantioselectivity. Surely, if larger libraries of this type are constructed, more selective catalysts will be uncovered.

\section{Experimental Section}

General Considerations. Unless stated otherwise, reactions were carried out under an inert atmosphere of nitrogen or argon using standard Schlenk techniques. THF was distilled from sodium benzophenone ketyl; $\mathrm{CH}_{2} \mathrm{Cl}_{2}$ was distilled from $\mathrm{CaH}_{2}$, and toluene was distilled from sodium under nitrogen. Triethylamine was distilled from $\mathrm{CaH}_{2}$ under nitrogen. With the exception of the compounds given below, all reagents were purchased from commercial suppliers and used without further purification. The following ligand precursor compounds were synthesized according to published procedures: phosphorochloridite of $(S)$ - and $(R)-2,2^{\prime}$-bisnaphthol, ${ }^{22}$ phosphorochloridite of $(R)$-3,3'-dimethyl-2,2'-bisnaphthol, ${ }^{23}$ and $N, N$-dibenzylurea. ${ }^{24} \mathrm{NMR}$ spectra were measured on a Varian Mercury $\left({ }^{1} \mathrm{H}\right.$ : $300 \mathrm{MHz},{ }^{31} \mathrm{P}\left\{{ }^{1} \mathrm{H}\right\}: 121.5 \mathrm{MHz},{ }^{13} \mathrm{C}\left\{{ }^{1} \mathrm{H}\right\}: 75.5 \mathrm{MHz}$ ) or a Varian Inova spectrometer $\left({ }^{1} \mathrm{H}: 500 \mathrm{MHz},{ }^{31} \mathrm{P}\left\{{ }^{1} \mathrm{H}\right\}: 202.3 \mathrm{MHz}\right.$, ${ }^{13} \mathrm{C}\left\{{ }^{1} \mathrm{H}\right\}: 125.7 \mathrm{MHz}$ ) using dry solvents at room temperature unless stated otherwise. Chemical shifts are reported in $\mathrm{ppm}$ and are given relative to TMS $\left({ }^{1} \mathrm{H}\right.$ and $\left.{ }^{13} \mathrm{C}\left\{{ }^{1} \mathrm{H}\right\}\right)$ or $\mathrm{H}_{3} \mathrm{PO}_{4}\left({ }^{31} \mathrm{P}\left\{{ }^{1} \mathrm{H}\right\}\right)$ as external standards. High-pressure NMR experiments were conducted using a glass NMR tube (New Era Enterprises, NEHP5-M). 2D-NMR spectra were measured using a HMQC

(22) Buisman, G. J. H.; van der Veen, L. A.; Klootwijk, A.; de Lange, W. G. J.; Kamer, P. C. J.; van Leeuwen, P. W. N. M.; Vogt, D. Organometallics 1997, 16, 2929-2939.

(23) Huttenloch, O.; Laxman, E.; Waldmann, H. Chem.-Eur. J. 2002, 8, 4767-4780.

(24) Shi, F.; Smith, M. R.; Maleczka, R. E. Org. Lett. 2006, $1411-1414$. 
pulse sequence without gradient. High-resolution mass spectra (HRMS) were recorded at the department of mass spectrometry at the University of Amsterdam using $\mathrm{FAB}^{+}$ionization on a JEOL JMS SX/SX102A four-sector mass spectrometer with 3-nitrobenzyl alcohol as the matrix. IR spectra were recorded on a Thermo Nicolet Nexus 670 FT-IR apparatus. High-pressure IR were carried out in a stainless steel $50 \mathrm{~mL}$ autoclave equipped with INTRAN windows ( $\mathrm{ZnS})$, a mechanical stirrer, a temperature controller, and a pressure indicator.

Synthesis of $(2 R, 5 R)-2,5$-Diphenylpyrrolidine-1-carboxamide. ( $2 R, 5 R)-2,5$-Diphenylpyrrolidine $(1.12 \mathrm{~g}, 1$ equiv, $5 \mathrm{mmol})$ was placed in a round-bottom flask. Then $200 \mathrm{~mL}$ of distilled water was added, and the resulting suspension was vigorously stirred. A $2.75 \mathrm{~mL}$ portion of a $2 \mathrm{M}$ aqueous $\mathrm{HCl}$ solution $(5.5 \mathrm{mmol}, 1.1$ equiv) was added dropwise to the reaction mixture. After stirring for $1 \mathrm{~h}$ the reaction mixture turned clear and a solution of $7.5 \mathrm{mmol}$ of $\mathrm{KOCN}(0.61 \mathrm{~g}, 1.5$ equiv) in distilled water was added. The reaction mixture was next stirred for $48 \mathrm{~h}$ while the product precipitated from the reaction mixture. The product was filtered from the turbid reaction mixture and washed $3 \times$ with water and $3 \times$ with hexanes. Yield: $0.93 \mathrm{~g}(70 \%)$ as a white powder. ${ }^{1} \mathrm{H}$ NMR $\left(300 \mathrm{MHz}, \mathrm{CDCl}_{3}\right): \delta 1.74\left(\mathrm{~d}, 2 \mathrm{H}, \mathrm{CH}_{2}\right.$, $J=6.3 \mathrm{~Hz}), 2.48\left(\mathrm{br}, 2 \mathrm{H}, \mathrm{CH}_{2}\right), 4.31\left(\mathrm{~s}, 2 \mathrm{H}, \mathrm{NH}_{2}\right), 5.04(\mathrm{br}, 1 \mathrm{H}$, $\mathrm{CH}), 5.46(\mathrm{br}, 1 \mathrm{H}, \mathrm{CH}), 7.2-7.5(\mathrm{ArH}, 10 \mathrm{H}) .{ }^{13} \mathrm{C}\left\{{ }^{1} \mathrm{H}\right\} \mathrm{NMR}$ $\left(75.5 \mathrm{MHz}, \mathrm{CDCl}_{3}\right): \delta 31.342,33.380,62.157,125.422,125.923$, 126.910, 128.107, 128.657, 129.336, 142.390, 143.846, 157.288 $\left(\mathrm{NH}_{2} \mathrm{CON}\right)$. HRMS $\left(\mathrm{FAB}^{+}\right): m / z$ calcd for $\mathrm{C}_{17} \mathrm{H}_{19} \mathrm{~N}_{2} \mathrm{O}$ $\left([\mathrm{MH}]^{+}\right)$267.1497, obsd 267.1501.

General Procedure for Phosphinourea Synthesis (phosphorus amide). $N, N$-Disubstituted urea ( $2 \mathrm{mmol}, 1$ equiv) was dried via coevaporation with toluene $(3 \times)$ and dissolved in $40 \mathrm{~mL}$ of THF. After that the vigorously stirred reaction mixture was cooled to $0{ }^{\circ} \mathrm{C}$, and $2.2 \mathrm{mmol}$ (1.1 equiv) of $n$-BuLi was added dropwise. After $10 \mathrm{~min} 2 \mathrm{mmol}$ of $\mathrm{Ph}_{2} \mathrm{PCl}$ (1 equiv) was added dropwise to the vigorously stirred reaction mixture. The reaction mixture was allowed to heat to room temperature and stirred for $1 \mathrm{~h}$. The reaction mixture was filtered over basic alumina, which washed with $2 \times 10 \mathrm{~mL}$ of THF. The solvents from the collected filtrate were evaporated in vacuo. The product was redissolved in $20 \mathrm{~mL}$ of $\mathrm{CH}_{2} \mathrm{Cl}_{2}$ and filtered over a silica plug. The solvents of the collected filtrate were evaporated in vacuo to obtain the product.

HL1 (1,1-dibenzyl-3-(diphenylphosphino)urea). Yield: 47\%, white powder. ${ }^{1} \mathrm{H} \mathrm{NMR}\left(\mathrm{CDCl}_{3}, 500 \mathrm{MHz}\right): \delta 4.58(\mathrm{~s}, 4 \mathrm{H}$, $\left.\mathrm{CH}_{2}\right), 5.04\left(\mathrm{~d}, 1 \mathrm{H}, \mathrm{NH},{ }^{2} J_{\mathrm{H}-\mathrm{P}}=6.9 \mathrm{~Hz}\right), 7.0-7.6(\mathrm{~m}, 20 \mathrm{H}$, ArH $).{ }^{31} \mathrm{P}\left\{{ }^{1} \mathrm{H}\right\}$ NMR $\left(\mathrm{CDCl}_{3}, 202.3 \mathrm{MHz}\right): \delta 25.518 .{ }^{31} \mathrm{P}$ NMR $\left(\mathrm{CD}_{2} \mathrm{Cl}_{2}, 202.3 \mathrm{MHz}\right): \delta 25.518\left(\mathrm{~d},{ }^{2} J_{\mathrm{P}-\mathrm{H}}=6.7 \mathrm{~Hz}\right) .{ }^{13} \mathrm{C}\left\{{ }^{1} \mathrm{H}\right\}$ NMR $\left(\mathrm{CDCl}_{3}, 125.7 \mathrm{MHz}\right): \delta 51.465\left(\mathrm{CH}_{2}\right), 127.498(\mathrm{CH})$, $127.739(\mathrm{CH}), 128.528(\mathrm{CH}), 128.579(\mathrm{CH}), 128.958(\mathrm{CH})$, $129.207(\mathrm{CH}), 130.996(\mathrm{CH}), 131.171(\mathrm{CH}), 137.732\left(\mathrm{C}_{\text {quat }}\right)$, $139.713\left(\mathrm{C}_{\text {quat }}\right), 139.837\left(\mathrm{C}_{\text {quat }}\right), 158.264\left(\mathrm{~d}, \mathrm{NHCON},{ }^{2} J_{\mathrm{C}-\mathrm{P}}=\right.$ $15 \mathrm{~Hz})$. HRMS $\left(\mathrm{FAB}^{+}\right): m / z$ calcd for $\mathrm{C}_{27} \mathrm{H}_{26} \overline{\mathrm{N}}_{2} \mathrm{OP}\left([\mathrm{MH}]^{+}\right)$ 425.1783, obsd 425.1790. Solution IR $\left(10 \mathrm{mM}, \mathrm{CDCl}_{3}\right): v=$ $3412 \mathrm{~cm}^{-1}$ (NH band), $1650 \mathrm{~cm}^{-1}$ (CO band).

$H L 4((2 R, 5 R)-N$-(diphenylphosphino)-2,5-diphenylpyrrolidine1-carboxamide). Yield: $75 \%$, white powder. ${ }^{1} \mathrm{H}$ NMR $(300 \mathrm{MHz}$, $\left.\mathrm{CD}_{2} \mathrm{Cl}_{2}\right): \delta 1.81\left(\mathrm{~d}, 2 \mathrm{H}, \mathrm{CH}_{2}, J=5.7 \mathrm{~Hz}\right), 2.56\left(\mathrm{~s}, 2 \mathrm{H}, \mathrm{CH}_{2}\right), 4.82$ $\left(\mathrm{d}, 1 \mathrm{H}, \mathrm{NH},{ }^{2} J_{\mathrm{H}-\mathrm{P}}=7.5 \mathrm{~Hz}\right), 5.10(\mathrm{br}, 1 \mathrm{H}, \mathrm{CH}), 5.56(\mathrm{br}, 1 \mathrm{H}$, $\mathrm{CH}), 6.7-7.5(\mathrm{ArH}, 20 \mathrm{H}) .{ }^{31} \mathrm{P}\left\{{ }^{1} \mathrm{H}\right\} \mathrm{NMR}\left(125.7 \mathrm{MHz}, \mathrm{CD}_{2} \mathrm{Cl}_{2}\right)$ : $\delta 23.53 .{ }^{13} \mathrm{C}\left\{{ }^{1} \mathrm{H}\right\}$ NMR $\left(75.5 \mathrm{MHz}, \mathrm{CD}_{2} \mathrm{Cl}_{2}\right): \delta 31.289,33.400$, $62.417,125.381,126.036,126.733,128.249,128.331,128.493$, $128.584,128.620,129.302,130.126,130.406,131.203,131.499$, $139.716,139.785,139.902,140.007,142.891,144.204,155.569$ (d, NHCON, $\left.{ }^{2} J_{\mathrm{C}-\mathrm{P}}=18 \mathrm{~Hz}\right)$. HRMS $\left(\mathrm{FAB}^{+}\right): m / z$ calcd for $\mathrm{C}_{29} \overline{\mathrm{H}}_{28} \mathrm{~N}_{2} \mathrm{OP}\left([\mathrm{MH}]^{+}\right)$451.1939, obsd 451.1935.

General Procedure for Phosphinourea Synthesis (phosphoramidite). $N, N$-Disubstituted urea ( $2 \mathrm{mmol}, 1$ equiv) was dried via coevaporation with toluene $(3 \times)$, dissolved in $40 \mathrm{~mL}$ of $\mathrm{THF}$, and cooled to $0^{\circ} \mathrm{C}$, and an excess of dry triethylamine was added. After $10 \mathrm{~min} 2 \mathrm{mmol}$ of phosphorchloridite (1 equiv) dissolved in $10 \mathrm{~mL}$ of THF was added dropwise to the reaction mixture, which was stirred for $12 \mathrm{~h}$. The product mixture was filtered over a basic alumina plug. Solvents were evaporated in vacuo. The product was redissolved in $\mathrm{CH}_{2} \mathrm{Cl}_{2}$ and filtered over a silica plug. The solvents were evaporated in vacuo to obtain the product. The ligands $\boldsymbol{H} \mathbf{L} \mathbf{2}, \boldsymbol{H} \mathbf{L} 3, \boldsymbol{H L 5}$, and $\boldsymbol{H} \mathbf{L} 6$ were obtained in a yield of $20-30 \%$ after filtration over silica.

HL2 $((S)$-1,1-dibenzyl-3-(dinaphtho[2,1-d:1', 2'-f][1,3,2]dioxaphosphepin-4-yl)urea). White powder. ${ }^{1} \mathrm{H}$ NMR $\left(\mathrm{CD}_{2} \mathrm{Cl}_{2}, 500\right.$ MHz): $\delta 4.325$ (br d, $2 \mathrm{H}, \mathrm{CH}_{2}$ ), 4.553 (br s, $2 \mathrm{H}, \mathrm{CH}_{2}$ ), 5.687 $\left(\mathrm{d}, 1 \mathrm{H}, \mathrm{NH},{ }^{2} J_{\mathrm{H}-\mathrm{P}}=6.5 \mathrm{~Hz}\right), 7.1-7.6(\mathrm{~m}, 18 \mathrm{H}, \mathrm{ArH}), 7.8-8.1$ (m, 4H, ArH). ${ }^{31} \mathrm{P}\left\{{ }^{1} \mathrm{H}\right\}$ NMR $\left(\mathrm{CD}_{2} \mathrm{Cl}_{2}, 121.5 \mathrm{MHz}\right): \delta 144.459$. ${ }^{31} \mathrm{P}$ NMR $\left(\mathrm{CD}_{2} \mathrm{Cl}_{2}, 121.5 \mathrm{MHz}\right): \delta 144.459\left(\mathrm{~d},{ }^{2} J_{\mathrm{P}-\mathrm{H}}=6.0 \mathrm{~Hz}\right)$. ${ }^{13} \mathrm{C}\left\{{ }^{1} \mathrm{H}\right\} \operatorname{NMR}\left(\mathrm{CD}_{2} \mathrm{Cl}_{2}, 125.7 \mathrm{MHz}\right): \delta 50.300\left(\mathrm{CH}_{2}\right), 121.420$ $(\mathrm{CH}), 121.759(\mathrm{CH}), 123.606\left(\mathrm{C}_{\text {quat }}\right), 124.257\left(\mathrm{C}_{\text {quat }}\right), 124.301$ $\left(\mathrm{C}_{\text {quat }}\right), 125.117(\mathrm{CH}), 125.271(\mathrm{CH}), 125.322(\mathrm{CH}), 126.366$ $(\mathrm{CH}), 126.480(\mathrm{CH}), 126.608(\mathrm{CH}), 126.715(\mathrm{CH}), 127.330$ $(\mathrm{CH}), 127.689(\mathrm{CH}), 128.246(\mathrm{CH}), 128.478(\mathrm{CH}), 128.518$ $(\mathrm{CH}), 128.820(\mathrm{CH}), 129.056(\mathrm{CH}), 130.076(\mathrm{CH}), 130.718$ $(\mathrm{CH}), 131.319\left(\mathrm{C}_{\text {quat }}\right), 131.762\left(\mathrm{C}_{\text {quat }}\right), 132.668\left(\mathrm{C}_{\text {quat }}\right), 132.762$ $\left(\mathrm{C}_{\text {quat }}\right), 146.845\left(\mathrm{C}_{\text {quat }}\right), 146.875\left(\mathrm{C}_{\text {quat }}\right), 148.500\left(\mathrm{C}_{\text {quat }}\right), 157.185$ $\left(\mathrm{d}, \mathrm{NHCON},{ }^{2} J_{\mathrm{C}-\mathrm{P}}=15 \mathrm{~Hz}\right)$. HRMS $\left(\mathrm{FAB}^{+}\right): \mathrm{m} / \mathrm{z}$ calcd for $\mathrm{C}_{35} \overline{\mathrm{H}}_{28} \mathrm{O}_{3} \mathrm{~N}_{2} \mathrm{P}\left([\mathrm{MH}]^{+}\right)$555.1838, obsd 555.1832. Solution IR $\left(10 \mathrm{mM}, \mathrm{CDCl}_{3}\right): v=3408 \mathrm{~cm}^{-1}$ ( $\mathrm{NH}_{\text {free }}$ band), $1646 \mathrm{~cm}^{-1}$ $\left(\mathrm{CO}_{\text {urea }}\right.$ band).

HL3 ((R)-3-(dinaphtho[2,1-d:1',2'-f][1,3,2] dioxaphosphepin-4yl)-1,1-dimethylurea). White powder. ${ }^{1} \mathrm{H}$ NMR $\left(\mathrm{CDCl}_{3}, 500\right.$ $\mathrm{MHz}): \delta 2.86\left(\mathrm{~s}, 6 \mathrm{H}, \mathrm{CH}_{3}\right), 5.56\left(\mathrm{~d}, 1 \mathrm{H}, \mathrm{NH},{ }^{2} J_{\mathrm{H}-\mathrm{P}}=6.0 \mathrm{~Hz}\right)$, 7.2-7.6 (m, 8H, ArH), 7.9-8.1 (m, 4H, ArH). ${ }^{31} \mathrm{P}\left\{{ }^{1} \mathrm{H}\right\}$ NMR $\left(\mathrm{CDCl}_{3}, 202.3 \mathrm{MHz}\right): \delta$ 144.298. ${ }^{13} \mathrm{C}\left\{{ }^{1} \mathrm{H}\right\}$ NMR $\left(\mathrm{CDCl}_{3}, 125.7\right.$ $\mathrm{MHz}): \delta 36.424\left(\mathrm{CH}_{3}\right), 121.542(\mathrm{CH}), 122.121(\mathrm{CH}), 123.933$ $\left(\mathrm{C}_{\text {quat }}\right), 123.950\left(\mathrm{C}_{\text {quat }}\right), 124.323\left(\mathrm{C}_{\text {quat }}\right), 124.365\left(\mathrm{C}_{\text {quat }}\right), 125.151$ $(\mathrm{CH}), 125.266(\mathrm{CH}), 126.441(\mathrm{CH}), 126.483(\mathrm{CH}), 126.908(\mathrm{CH})$, $126.976(\mathrm{CH}), 128.317(\mathrm{CH}), 128.490(\mathrm{CH}), 128.515(\mathrm{CH})$, $128.127(\mathrm{CH}), 129.852(\mathrm{CH}), 130.750(\mathrm{CH}), 131.302\left(\mathrm{C}_{\text {quat }}\right)$, 131.739 ( $\left.\mathrm{C}_{\text {quat }}\right), 132.820\left(\mathrm{C}_{\text {quat }}\right), 147.022\left(\mathrm{C}_{\text {quat }}\right), 147.054$ $\left(\mathrm{C}_{\text {quat }}\right), 148.605\left(\mathrm{C}_{\text {quat }}\right), 156.906\left(\mathrm{~d}, \mathrm{NHCON},{ }^{2} J_{\mathrm{C}-\mathrm{P}}=15 \mathrm{~Hz}\right)$. HRMS $\left(\mathrm{FAB}^{+}\right): m / z$ calcd for $\mathrm{C}_{23} \mathrm{H}_{20} \mathrm{~N}_{2} \mathrm{O}_{3} \mathrm{P}\left([\mathrm{MH}]^{+}\right) 403.1212$, obsd 403.1216 .

HL5 ((R)-1,1-dibenzyl-3-(2,6-dimethyldinaphtho[2,1-d:1',2'-f]$[1,3,2]$ dioxaphosphepin-4-yl)urea). White powder. ${ }^{1} \mathrm{H}$ NMR $\left(\mathrm{CD}_{2} \mathrm{Cl}_{2}, 500 \mathrm{MHz}\right): \delta 2.48\left(\mathrm{~s}, 3 \mathrm{H}, \mathrm{CH}_{3}\right), 2.58\left(\mathrm{~s}, 3 \mathrm{H}, \mathrm{CH}_{3}\right), 4.3$ (br, $\left.2 \mathrm{H}, \mathrm{CH}_{2}\right), 4.5\left(\mathrm{br}, 2 \mathrm{H}, \mathrm{CH}_{2}\right), 5.72\left(\mathrm{~d}, 1 \mathrm{H}, \mathrm{NH},{ }^{2} J_{\mathrm{H}-\mathrm{P}}=6.9\right.$ $\mathrm{Hz}), 7.1-7.9(\mathrm{~m}, 20 \mathrm{H}, \mathrm{ArH}) .{ }^{31} \mathrm{P}\left\{{ }^{1} \mathrm{H}\right\}$ NMR $\left(\mathrm{CD}_{2} \mathrm{Cl}_{2}, 202.3\right.$ $\mathrm{MHz}): \delta 143.787 .{ }^{13} \mathrm{C} \mathrm{NMR}\left(\mathrm{CD}_{2} \mathrm{Cl}_{2}, 75.5 \mathrm{MHz}\right): \delta 17.178$, $17.422,50.336,123.418,123.450,124.297,124.371,124.961$, $125.143,125.249,125.379,126.480,126.508,127.407$ (br), $127.593,127.693,128.765,129.687,130.075,130.169,130.190$, $130.347,131.110,131.354,131.373,131.479,11.500,131.554$, 136.708 (br), 146.218, 146.271, 147.520, 147.543, 157.206 $\left(\mathrm{d}, \mathrm{NHCON},{ }^{2} J_{\mathrm{C}-\mathrm{P}}=16 \mathrm{~Hz}\right)$. HRMS $\left(\mathrm{FAB}^{+}\right): m / z$ calcd for $\mathrm{C}_{37} \mathrm{H}_{32} \overline{\mathrm{O}}_{3} \mathrm{~N}_{2} \mathrm{P}\left([\mathrm{MH}]^{+}\right)$583.2151, obsd 583.2154.

HL6 $\left((2 S, 5 S)-N-\left((11 b R)\right.\right.$-dinaphtho[2,1-d:1', $\left.2^{\prime}-f\right][1,3,2]$ dioxaphosphepin-4-yl)-2,5-diphenylpyrrolidine-1-carboxamide). White powder. ${ }^{1} \mathrm{H}$ NMR $\left(\mathrm{CD}_{2} \mathrm{Cl}_{2}, 500 \mathrm{MHz}\right): \delta 1.77\left(\mathrm{~s}, 2 \mathrm{H}, \mathrm{CH}_{2}\right), 2.48$ (br, $\left.2 \mathrm{H}, \mathrm{CH}_{3}\right), 4.78(\mathrm{~s}, 1 \mathrm{H}, \mathrm{CH}), 5.25\left(\mathrm{~d}, 1 \mathrm{H}, \mathrm{NH},{ }^{2} J_{\mathrm{H}-\mathrm{P}}=5.5\right.$ $\mathrm{Hz}), 5.56(\mathrm{~s}, 1 \mathrm{H}, \mathrm{CH}), 7.0-7.6(\mathrm{~m}, 18 \mathrm{H}, \mathrm{ArH}), 7.8-8.2(\mathrm{~m}, 4 \mathrm{H}$, ArH $).{ }^{31} \mathrm{P}\left\{{ }^{1} \mathrm{H}\right\}$ NMR $\left(\mathrm{CD}_{2} \mathrm{Cl}_{2}, 202.3 \mathrm{MHz}\right): \delta 145.497 .{ }^{13} \mathrm{C}\left\{{ }^{1} \mathrm{H}\right\}$ NMR $\left(\mathrm{CD}_{2} \mathrm{Cl}_{2}, 75.5 \mathrm{MHz}\right): \delta 31.015\left(\mathrm{CH}_{2}\right), 33.410\left(\mathrm{CH}_{2}\right)$, $62.056(\mathrm{CH}), 121.446(\mathrm{CH}), 122.121(\mathrm{CH}), 123.872\left(\mathrm{C}_{\text {quat }}\right)$, $123.974\left(\mathrm{C}_{\text {quat }}\right), 124.016\left(\mathrm{C}_{\text {quat }}\right), 124.994(\mathrm{CH}), 125.043(\mathrm{CH})$, $125.357(\mathrm{CH}), 126.229(\mathrm{CH}), 126.767(\mathrm{CH}), 126.904(\mathrm{CH})$, $127.734(\mathrm{CH}), 128.314(\mathrm{CH}), 128.515(\mathrm{CH}), 128.871(\mathrm{CH})$, $129.417(\mathrm{CH}), 130.410(\mathrm{CH}), 131.213\left(\mathrm{C}_{\text {quat }}\right), 131.478\left(\mathrm{C}_{\text {quat }}\right)$, 132.634 ( $\left.\mathrm{C}_{\text {quat }}\right), 132.737\left(\mathrm{C}_{\text {quat }}\right), 141.253$ ( $\left.\mathrm{C}_{\text {quat }}\right), 143.421\left(\mathrm{C}_{\text {quat }}\right)$, $146.912\left(\mathrm{C}_{\text {quati }}\right), 146.942\left(\mathrm{C}_{\text {quat }}\right), 148.428\left(\mathrm{C}_{\text {quat }}\right), 154.932$ (d, NHCON, $\left.{ }^{2} J_{\mathrm{C}-\mathrm{P}}=15 \mathrm{~Hz}\right)$. HRMS $\left(\mathrm{FAB}^{+}\right): m / z$ calcd for $\mathrm{C}_{37} \mathrm{H}_{30} \overline{\mathrm{O}}_{3} \mathrm{~N}_{2} \mathrm{P}\left([\mathrm{MH}]^{+}\right)$581.1994, obsd 581.1999.

General Procedure for Complex Synthesis. To a Schlenk filled with $1 \mathrm{mmol}$ (2 equiv) of phosphinourea ligand and $0.5 \mathrm{mmol}$ 
(129 mg, 1 equiv) of $\left[\mathrm{Rh}(\mathrm{acac})(\mathrm{CO})_{2}\right]$ was added $10 \mathrm{~mL}$ of $\mathrm{CH}_{2} \mathrm{Cl}_{2}$. Instantaneously $\mathrm{CO}$ gas was released from the clear yellow reaction mixture. After five minutes of vigorous stirring, solvents were evaporated in vacuo. Hacac (acetylacetone) present as a side-product was removed via coevaporation with toluene $(3 \times)$. The complexes were formed in high purity $(>95 \%$ based on ${ }^{31} \mathrm{P}\left\{{ }^{1} \mathrm{H}\right\}$ NMR) and were used without further purification.

Complex $\left[\mathbf{R h}(\boldsymbol{H L} 1-\kappa P)\left(\mathbf{L} 1-\kappa^{2} \boldsymbol{O}, \boldsymbol{P}\right)(\mathbf{C O})\right]$. Yellow-orange powder. ${ }^{1} \mathrm{H}$ NMR $\left(\mathrm{CD}_{2} \mathrm{Cl}_{2}, 500 \mathrm{MHz}\right): \delta 4.24\left(\mathrm{~s}, 6 \mathrm{H}, \mathrm{CH}_{2}\right), 4.81(\mathrm{~s}$, $\left.2 \mathrm{H}, \mathrm{CH}_{2}\right), 6.4\left(\mathrm{~d}, 1 \mathrm{H}, \mathrm{NH},{ }^{2} J_{\mathrm{H}-\mathrm{P}}=16.5 \mathrm{~Hz}\right), 7.0-7.8(\mathrm{~m}, 40 \mathrm{H}$, ArH). ${ }^{31} \mathrm{P}\left\{{ }^{1} \mathrm{H}\right\}$ NMR $\left(\mathrm{CD}_{2} \mathrm{Cl}_{2}, 202.3 \mathrm{MHz}\right): \delta 62.9\left(\mathrm{dd},{ }^{1} J_{\mathrm{Rh}-\mathrm{P}}=\right.$ $\left.135 \mathrm{~Hz},{ }^{2} J_{\mathrm{P}-\mathrm{P}}=326 \mathrm{~Hz}\right), 82.0\left(\mathrm{dd},{ }^{1} J_{\mathrm{Rh}-\mathrm{P}}=129 \mathrm{~Hz},{ }^{2} J_{\mathrm{P}-\mathrm{P}}=326\right.$ $\mathrm{Hz}) .{ }^{31} \mathrm{P}$ NMR $\left(\mathrm{CDCl}_{3}, 202.3 \mathrm{MHz}\right): \delta 62.9\left(\mathrm{dddt},{ }^{1} J_{\mathrm{Rh}-\mathrm{P}}=135\right.$ $\left.\mathrm{Hz},{ }^{2} J_{\mathrm{P}-\mathrm{P}}=326 \mathrm{~Hz},{ }^{2} J_{\mathrm{P}-\mathrm{H}}=14.6 \mathrm{~Hz},{ }^{3} J_{\mathrm{Ar}-\mathrm{H}}=11.7 \mathrm{~Hz}\right), 82.0(\mathrm{ddt}$, $\left.{ }^{1} J_{\mathrm{Rh}-\mathrm{P}}=129 \mathrm{~Hz},{ }^{2} J_{\mathrm{P}-\mathrm{P}}=326 \mathrm{~Hz},{ }^{3} J_{\mathrm{Ar}-\mathrm{H}}=11 \mathrm{~Hz}\right) .{ }^{13} \mathrm{C}\left\{{ }^{1} \mathrm{H}\right\}$ NMR $\left(\mathrm{CD}_{2} \mathrm{Cl}_{2}, 125.7 \mathrm{MHz}\right): \delta 49.605\left(\mathrm{CH}_{2}\right), 50.406\left(\mathrm{CH}_{2}\right)$, $126.877(\mathrm{CH}), 127.492(\mathrm{CH}), 127.573(\mathrm{CH}), 127.703(\mathrm{CH})$, $127.796(\mathrm{CH}), 128.072(\mathrm{CH}), 128.158(\mathrm{CH}), 128.306(\mathrm{CH})$, $128.391(\mathrm{CH}), 128.731(\mathrm{CH}), 129.846(\mathrm{CH}), 130.541(\mathrm{CH})$, $131.301(\mathrm{CH}), 131.402(\mathrm{CH}), 132.934(\mathrm{CH}), 133.057(\mathrm{CH})$, $133.625\left(\mathrm{C}_{\text {quat }}\right), 134.003\left(\mathrm{C}_{\text {quat }}\right), 136.948\left(\mathrm{C}_{\text {quat }}\right), 138.682\left(\mathrm{C}_{\text {quat }}\right)$, $138.755\left(\mathrm{C}_{\text {quat }}\right), 139.218\left(\mathrm{C}_{\text {quat }}\right), 155.424\left(\mathrm{~d}, \mathrm{C}_{\text {quat }},{ }^{2} J_{\mathrm{C}-\mathrm{P}}=7.4 \mathrm{~Hz}\right.$, $(\mathrm{NHCON}), 175.5\left(\mathrm{dd}, \mathrm{C}_{\text {quat }},{ }^{2} J_{\mathrm{C}-\mathrm{Rh}}=27 \mathrm{~Hz},{ }^{2} J_{\mathrm{C}-\mathrm{P}}=8.8 \mathrm{~Hz}\right.$, NCON), 192 (br d, $\mathrm{C}_{\text {quat }},{ }^{1} J_{\mathrm{C}-\mathrm{Rh}} \approx 73 \mathrm{~Hz}, \mathrm{Rh}-\mathrm{CO}$ ). HRMS $\left(\overline{\mathrm{FAB}}{ }^{+}\right): m / z$ calcd for $\mathrm{C}_{54} \mathrm{H}_{49} \mathrm{~N}_{4} \mathrm{O}_{2} \mathrm{P}_{2} \mathrm{Rh}\left([\mathrm{MH}]^{+}\right)$950.2386, obsd 950.2380 (CO ligand dissociated). Solution IR (10 mM, $\left.\mathrm{CDCl}_{3}\right)$ : $v=3381 \mathrm{~cm}^{-1}$ ( $\mathrm{NH}_{\text {assoc. }}$ band), $1970 \mathrm{~cm}^{-1}$ (Rh-CO band), 1663 $\mathrm{cm}^{-1}$ ( $\mathrm{CO}_{\text {urea }}$ band).

Complex $\left[\mathbf{R h}(\boldsymbol{H L} 2-\kappa P)\left(\mathbf{L} 2-\kappa^{2} \boldsymbol{O}, \boldsymbol{P}\right)(\mathrm{CO})\right]$. Yellow-orange powder. ${ }^{1} \mathrm{H}$ NMR $\left(\mathrm{CD}_{2} \mathrm{Cl}_{2}, 500 \mathrm{MHz}\right): \delta 4.2\left(\mathrm{~m}, 4 \mathrm{H}, \mathrm{CH}_{2}\right), 4.56(\mathrm{~s}$, $\left.3 \mathrm{H}, \mathrm{CH}_{2}\right), 5.88\left(\mathrm{~s}, 1 \mathrm{H}, \mathrm{CH}_{2}\right), 7.2-8.2(\mathrm{~m}, 45 \mathrm{H}, \mathrm{ArH}+\mathrm{NH})$. ${ }^{31} \mathrm{P}\left\{{ }^{1} \mathrm{H}\right\}$ NMR $\left(\mathrm{CD}_{2} \mathrm{Cl}_{2}, 202.3 \mathrm{MHz}\right): \delta 149.4\left(\mathrm{dd},{ }^{1} J_{\mathrm{Rh}-\mathrm{P}}=213\right.$ $\mathrm{Hz},{ }^{2} J_{\mathrm{P}-\mathrm{P}}=674 \mathrm{~Hz}, 170.0\left(\mathrm{dd},{ }^{1} J_{\mathrm{Rh}-\mathrm{P}}=189 \mathrm{~Hz},{ }^{2} J_{\mathrm{P}-\mathrm{P}}=672\right.$ $\mathrm{Hz})$. HRMS (FAB $\left.{ }^{+}\right): m / z$ calcd for $\mathrm{C}_{70} \mathrm{H}_{54} \mathrm{~N}_{4} \mathrm{O}_{6} \mathrm{P}_{2} \mathrm{Rh}\left([\mathrm{MH}]^{+}\right)$ 1211.2574, obsd 1211.2566 (CO ligand dissociated).

Complex $\left[\operatorname{Rh}(\boldsymbol{H L 1}-\kappa \boldsymbol{P})\left(\mathbf{L} 2-\kappa^{2} \boldsymbol{O}, \boldsymbol{P}\right)(\mathbf{C O})\right]$. Yellow-orange powder. ${ }^{1} \mathrm{H}$ NMR $\left(\mathrm{CD}_{2} \mathrm{Cl}_{2}, 500 \mathrm{MHz}\right): \delta 3.76\left(\mathrm{~d}, 1 \mathrm{H}, \mathrm{CH}_{2}, J=15.5\right.$ $\mathrm{Hz}), 4.07\left(\mathrm{~d}, 1 \mathrm{H}, \mathrm{CH}_{2}, J=15 \mathrm{~Hz}\right), 4.2\left(\mathrm{br}, 4 \mathrm{H}, \mathrm{CH}_{2}\right) 4.46(\mathrm{~d}, 1 \mathrm{H}$, $\left.\mathrm{CH}_{2}, J=15 \mathrm{~Hz}\right), 4.95\left(\mathrm{~d}, 1 \mathrm{H}, \mathrm{CH}_{2}, J=15.5 \mathrm{~Hz}\right), 6.33(\mathrm{~d}, 1 \mathrm{H}, \mathrm{NH}$, $\left.{ }^{2} J_{\mathrm{H}-\mathrm{P}}=17 \mathrm{~Hz}\right) 6.8-8.0(\mathrm{~m}, 42 \mathrm{H}, \mathrm{ArH}) .{ }^{31} \mathrm{P}\left\{{ }^{1} \mathrm{H}\right\} \operatorname{NMR}\left(\mathrm{CD}_{2} \mathrm{Cl}_{2}\right.$, $202.3 \mathrm{MHz}): \delta 63.3\left(\mathrm{dd},{ }^{1} J_{\mathrm{Rh}-\mathrm{P}}=131 \mathrm{~Hz},{ }^{2} J_{\mathrm{P}-\mathrm{P}}=451 \mathrm{~Hz}\right)$, $170.9\left(\mathrm{dd},{ }^{1} J_{\mathrm{Rh}-\mathrm{P}}=190 \mathrm{~Hz},{ }^{2} J_{\mathrm{P}-\mathrm{P}}=451 \mathrm{~Hz}\right) .{ }^{31} \mathrm{P} \mathrm{NMR}\left(\mathrm{CD}_{2} \mathrm{Cl}_{2}\right.$, $202.3 \mathrm{MHz}): \delta 63.3\left(\mathrm{dddt},{ }^{1} J_{\mathrm{Rh}-\mathrm{P}}=131 \mathrm{~Hz},{ }^{2} J_{\mathrm{P}-\mathrm{P}}=451 \mathrm{~Hz}\right.$, $\left.{ }^{2} J_{\mathrm{P}-\mathrm{H}}=13.8 \mathrm{~Hz},{ }^{3} J_{\mathrm{Ar}-\mathrm{H}}=12.5 \mathrm{~Hz}\right) 170.9\left(\mathrm{dd},{ }^{1} J_{\mathrm{Rh}-\mathrm{P}}=190 \mathrm{~Hz}\right.$, $\left.{ }^{2} J_{\mathrm{P}-\mathrm{P}}=451 \mathrm{~Hz}\right)$. HRMS $\left(\mathrm{FAB}^{+}\right): m / z$ calcd for $\mathrm{C}_{62} \mathrm{H}_{52} \mathrm{O}_{4} \mathrm{~N}_{4} \mathrm{P}_{2} \mathrm{Rh}$ $\left([\mathrm{MH}]^{+}\right) 1081.2519$, obsd 1081.2521 (CO ligand dissociated).

General Procedure for Hydroformylation Experiments. The hydroformylation experiments were carried out in a stainless steel autoclave (volume $150 \mathrm{~mL}$ ) with an insert for five $2 \mathrm{~mL}$ glass reaction vials. The reaction vials were dried in an oven $\left(135^{\circ} \mathrm{C}\right)$, capped with a septum, and flushed with inert gas (argon) before use. In each reaction vial the catalyst was made in situ by charging the reaction vial with the appropriate amounts of metal precursor and ligands before it was flushed again with inert gas. The substrate (styrene) was filtered freshly over basic alumina to remove peroxide impurities. The substrate was dissolved in $\mathrm{CH}_{2} \mathrm{Cl}_{2}$ at the appropriate molarity and was injected into the reaction vials. The insert containing the reaction vials was placed in the autoclave, which was closed thoroughly. Before starting the catalytic reaction, the prepared autoclave was purged three times with 10 bar of syngas $\left(\mathrm{CO} / \mathrm{H}_{2}=1: 1\right)$ and then pressurized to the appropriate pressure. The pressure in the autoclave during the reaction was monitored by either an analog or digital readout. The reaction was stopped by cooling the autoclave with ice, and the autoclave was subsequently slowly depressurized. Reaction samples were prepared and analyzed directly after the reaction by GC chromatography using an Interscience Focus GC equipped with a Supelco beta dex 225 column.

X-ray Crystallography of $\boldsymbol{H L 1} \mathrm{C}_{27} \mathrm{H}_{25} \mathrm{~N}_{2} \mathrm{OP}, \boldsymbol{M}_{\mathrm{w}}=424.46$, colorless rod, $0.32 \times 0.14 \times 0.10 \mathrm{~mm}^{3}$, triclinic, $P \overline{1}$ (No. 2 ), $a=$ 9.3963(4) $\AA, b=10.0852(4) \AA, c=20.8958(12) \AA, \alpha=92.021(2)^{\circ}$, $\beta=100.289(2)^{\circ}, \gamma=108.447(2)^{\mathrm{o}}, V=2203.99(18) \AA^{3}, Z=4$, $D_{\text {exptl }}=1.279 \mathrm{~g} / \mathrm{cm}^{3}, \mu($ Mo K $\alpha)=0.147 \mathrm{~mm}^{-1}, T=110 \mathrm{~K}$. X-ray data were collected $\left(\theta(\max )=27.5^{\circ} ;\right.$ total $=57422 ;$ unique $=$ 10124) on a Nonius KappaCCD with graphite-monochromated Mo $\mathrm{K} \alpha$ radiation $(\lambda=0.71073 \AA)$ under program control of COLLECT. ${ }^{25}$ The program PEAKREF ${ }^{26}$ was used to determine the cell dimensions. Data reduction was done using the program EVALCCD. ${ }^{27}$ Absorption correction based on faceindexing was done with SADABS. ${ }^{28}$ The structure was solved with SHELXS-97 ${ }^{29}$ and refined with SHELXL-97. ${ }^{29}$ Hydrogen atoms were introduced at calculated positions and refined riding on their carrier atoms with $U$ (iso) $=1.2 \times U_{\text {eq }}$ of the attached $\mathrm{C}$ atom. The $\mathrm{H}$ atoms attached to $\mathrm{N} 2 \mathrm{~A}$ and $\mathrm{N} 2 \mathrm{~B}$ were located from a difference map and refined with a distance restraint $[d(\mathrm{~N}-\mathrm{H})-0.88 \AA]$. Final $R=0.0415$ for 7278 reflections with $I>2 \sigma(I), w R_{2}=0.0948$ for 10124 reflections, $S=1.02$, $N_{\text {param }}=565$. The final difference map is essentially featureless with excursions in the range -0.36 to $0.43 \mathrm{e} / \AA^{3}$. The structure was validated with PLATON/CHECK. ${ }^{30}$ The cif file of $\mathbf{L 1}$ is supplied in the Supporting Information.

DFT Calculations. The geometry optimizations were carried out with the Turbomole program ${ }^{31}$ coupled to the PQS Baker optimizer. ${ }^{32}$ All geometries were optimized at the BP86 $6^{33}$ level using the $\mathrm{SV}(\mathrm{P})$ basis set $^{34}$ on all atoms (small-core pseudopotential $^{35}$ on rhodium). Optimized geometries of the species are supplied as a pdf file in the Supporting Information.

Acknowledgment. This research is financially supported by BASF The Netherlands and the Dutch Ministry of Economic Affairs by way of SenterNovem. J. W. H. Peeters is acknowledged for the mass spectrometry experiments, J. M. Ernsting for assistance with the 2D-NMR experiments, and Z. A biri for providing $N, N$-dibenzylurea.

Supporting Information Available: This material is available free of charge via the Internet at http://pubs.acs.org.

(25) COLLECT; Nonius BV: Delft, The Netherlands, 1999

(26) Schreurs, A. M. M. PEAKREF; Utrecht University: Utrecht, The Netherlands, 2005.

(27) Duisenberg, A. J. M.; Kroon-Batenburg, L. M. J.; Schreurs, A. M. M. J. Appl. Crystallogr. 2003, 36, 220-229.

(28) Sheldrick, G. M. SADABS 2006/1; University of Göttingen: Göttingen, Germany, 2006.

(29) Sheldrick, G. M. Acta Crystallogr., Sect. A 2008, 64, 112-122.

(30) Spek, A. L. Acta Crystallogr. Sect. D 2009, 65, 148-155.

(31) (a) Ahlrichs, R.; Bär, M.; Baron, H.-P.; Bauernschmitt, R.; Böcker, S.; Ehrig, M.; Eichkorn, K.; Elliott, S.; Furche, F.; Haase, F.; Häser, M.; Hättig, C.; Horn, H.; Huber, C.; Huniar, U.; Kattannek, M.; Köhn, A.; Kölmel, C.; Kollwitz, M.; May, K.; Ochsenfeld, C.; Öhm, H.; Schäfer, A.; Schneider, U.; Treutler, O.; Tsereteli, K.; Unterreiner, B.; von Arnim, M.; Weigend, F.; Weis, P.; Weiss, H. Turbomole Version 5; Theoretical Chemistry Group, University of Karlsruhe, 2002. (b) Treutler, O.; Ahlrichs, R. J. Chem. Phys. 1995, 102, 346-354.

(32) (a) $P Q S$ version 2.4; Parallel Quantum Solutions: Fayetteville, AR, 2001 (the Baker optimizer is available separately from PQS upon request). (b) Baker, J. J. Comput. Chem. 1986, 7, 385-395.

(33) (a) Becke, A. D. Phys. Rev. A 1988, 38, 3098-3100. (b) Perdew, J. P. Phys. Rev. B 1986, 33, 8822-8824.

(34) Schäfer, A.; Horn, H.; Ahlrichs, R. J. Chem. Phys. 1992, 97, 2571-2577.

(35) (a) Turbomole basis set library, Turbomole Version 5. (b) Andrae, D.; Haeussermann, U.; Dolg, M.; Stoll, H.; Preuss, H. Theor. Chim. Acta 1990, 77, 123-141. 